\title{
The Production of Black Ph.D.'s in Economics at Harvard University, 1905-1955
}

\author{
Samuel L. Myers Jr. ${ }^{1,2}$
}

Published online: 31 May 2017

(C) Springer Science+Business Media New York 2017

\begin{abstract}
Harvard University's Economics Department produced some of the leading African American economists between World War I and the Korean War. This essay explores the factors that contributed to this accomplishment and documents the career trajectories of the six blacks who obtained the Doctorate in Economics from Harvard University during the period 1905-1955. The analysis reveals the pivotal roles of the Rosenwald Fund, Classical High Schools, Black Fraternal Organizations and former University of Minnesota Applied Economics Professor, John D. Black. A common outcome of the careers of these six pioneers was a commitment to black economic empowerment.
\end{abstract}

Keywords History of economic thought $\cdot$ Black economists $\cdot$ John D. Black $\cdot$ Harvard University Ph.D. program in economics · Robert Weaver · William H. Dean, Jr. · Booker T. McGraw · Hastings Dudley Huggins · Samuel Lloyd Myers, Sr. · Samuel Z. Westerfield, Jr. - John D. Black, University of Minnesota

\section{Introduction}

Harvard University, established in 1637, has a reputation for being a trendsetter in higher education (Greene 2011; About Department of Econ-

Samuel Z. Westerfield, Jr. Award Lecture, January 5, 2015, National Economic Association and Allied Social Science Association Meetings, Boston Massachusetts.

Samuel L. Myers, Jr is the Roy Wilkins Professor of Human Relations and Social Justice.

Samuel L. Myers, Jr.

myers006@umn.edu

1 Humphrey School of Public Affairs, University of Minnesota, 301 19th Avenue South, Minneapolis, MN 55455, USA

2 Graduate Faculty, Applied Economics Ph.D. Program, University of Minnesota, 301 19th Avenue South, Minneapolis, MN 55455, USA 
omics). ${ }^{1}$ It was one of the first major research universities to guarantee full financial aid to all low-income students admitted (Otani 2015); it pioneered the use of a core curriculum (Bombardieri, 2004); was an early adopter of the SAT examination as a requirement for admission (History of the SAT); and notably, has been a leader in targeted admissions of students from underrepresented racial minority groups (Roberts 2015). There is a saying: "Harvard leads and higher education follows." 2

Harvard's Department of Economics, founded in 1897 (Mason and Lamont 1982), produced its first Ph.D. in 1905 (Harvard University 1900). Many faculty members throughout the first half of the twentieth Century received their doctorates from Harvard, creating a distinct and identifiable school of thought that ultimately became one of the dominant schools of thought in the United States (Harvard/Radcliffe). Key areas in the Economics Department at Harvard included the analysis of monopolistic competition, the extension of international trade theory, and in later years, it became a center for Keynesian economics in the United States (Mason and Lamont 1982). The Department helped to shape the training of economics throughout the entire nation throughout much of the twentieth Century.

This essay is rooted in dining room conversations with my father, Samuel L. Myers, Sr., a 1949 graduate of the Ph.D. Program in Economics at Harvard University. My father had produced a programmed textbook for teaching introductory economics at Morgan State College. ${ }^{3}$ He talked about his professors at Morgan who inspired him; his professors at Boston University who supported his interest in economic analysis of the Negro; and he detailed his experiences in the Ph.D. program in economics at Harvard University, recounting his interactions with Joseph A. Schumpeter, Gottfried Haberler, Alvin Hanson, John Dunlop, John Kenneth Galbraith, and most of all, John D. Black. ${ }^{4}$ It was during these conversations that my father modestly revealed that he was "only the fifth" black to obtain the Ph.D. in economics from Harvard University. This kernel of information apparently has remained unchallenged and unappreciated by economic historians and others interested in the role of race in the profession. Clearly, if my father were the fifth black to receive the Ph.D. in economics from Harvard, then there must be some record of the first, second, third and fourth recipients of this coveted degree. This essay is designed to document the evidence available concerning the production of black economists at Harvard from 1905 until 1955.

At my father's 95th birthday party, celebrated first at the Spring 2014 meeting of Gamma Boule of Sigma Pi Phi Fraternity ${ }^{5}$ and then at the headquarters of Minority

\footnotetext{
${ }^{1}$ When Harvard adopted restrictive admissions policies to limit access to Jewish students, so did other elite schools. "Harvard again proved to be the trendsetter in higher education, as other elite institutions - including Yale, Princeton, Columbia, and Dartmouth — altered admissions policies to decrease Jewish students' enrollment during the 1920s and 1930s." In essence, the actions of Harvard set precedents for other schools to follow (Greene 2011).

${ }^{2}$ Quote from John Blackburn, Admissions Dean at the University of Virginia, "Whenever Harvard does anything, it's more than a trickle down - there's a major effect," "When Harvard acts, it causes other people to say, 'That's the highest order of ethical behavior.'” (Powers 2006) See also Mulhere (2014) regarding possible changes in race-based admissions at Harvard.

${ }^{3}$ Much like Robert Bishop's "Bishop's Lectures," my father's programmed textbook was never published but was widely circulated, copied and used by many generations of Morgan economics students, including Black Enterprise Magazine founder and publisher, Earl Graves. For more, see Feathers (2013); Myers (2003).

${ }^{4}$ Samuel Myers, Jr. Interview with Samuel Myers, Sr. Interview transcript. March 2014.

${ }^{5}$ Sigma Pi Phi Fraternity, also known as the Boule, is the first Greek-letter fraternity to be founded by African American men. For more, see History of the Boulé.
} 
Access, Inc., ${ }^{6}$ I recounted more recent conversations with him designed to establish conclusively the identities of the doctoral recipients who preceded him at Harvard. With fading memory, my father speculated that the first might have been W.E.B. Dubois; the second probably was Abram Harris; the third possibly was someone by the name of Greene, who did mathematical location theory. This ordering conflicted with the widely documented evidence that the graduate economics department at Harvard had not yet been formed at the time that Dubois received his degree ${ }^{7}$; that Abram Harris received his degree from Columbia, not Harvard. ${ }^{8}$ And, a quick search of graduates of Harvard produced no one by the name of Greene with a thesis on location economics. In an entirely unguarded moment, I jokingly mentioned during the ceremonies that since the person my modest father thought was the first, could not have been the first; since the person who putatively was the second clearly was not first or second; and since the person who apparently was the third could not be found, that meant that perhaps my father was the first.

Given that the audience included major business executives, college presidents, top elected officials, and prominent leaders of the African American community in Baltimore, I immediately sensed the folly of making such casual claims. I was fortunate to have the assistance of a talented undergraduate student participating in the University of Minnesota's Ronald McNair summer mentorship program interested in the famed agricultural economist, John D. Black, whose picture adorns the graduate seminar room of the University of Minnesota's Department of Applied Economics. Black had been one of my father's senior mentors at Harvard with many vital links to Minnesota. Lawrence Karongo, with the help of Cheniqua Johnson, another undergraduate at the University of Minnesota, spent the summer of 2014 tracking down the dissertations of all doctoral recipients from Harvard's economics department and combing through public records, census records, newspaper and magazine accounts to identify the race and ethnicity of each of the 609 Ph.D. recipients in economics from 1905 to 1955.

This essay is the story of these efforts and provides insights into the production of black Ph.D.'s at, arguably, the leading economics department in the United States by the end of World War II. I will begin by discussing the methodology used to document the six black Harvard Ph.D.'s in economics during the period under review. In producing the list, I also report the dissertation topics, the dissertation advisors, and connections that heretofore have not been fully articulated. Then, I present estimates from a simple model that asks and answers the question: what are the key factors that contributed to the production of black Harvard Ph.D.'s in economics in any given year? The concluding section offers insights about the patterns, themes and linkages and their implications for the production of minority Ph.D.'s in the twenty-first Century.

\footnotetext{
${ }^{6}$ Minority Access is a nonprofit organization committed to increasing diversity, decreasing disparities and reducing incidences of environmental injustices. The mission is to assist colleges and universities, the Federal Government and agencies of other governments and corporations in implementing programs and providing services to recruit, enhance and retain underserved and underrepresented populations. For more, see Improving diversity in education, employment and research.

${ }^{7}$ Dubois completed his graduate studies in history in 1895. He was the first African American to earn a Ph.D. from Harvard University. For more, see NAACP History: W.E.B. Dubois.

${ }^{8}$ Abram Lincoln Harris Jr. received his $\mathrm{PhD}$ in economics in 1930 from Columbia University. For more, see Abram Harris Born.
} 


\section{Methodology}

The primary source of information on doctoral recipients from Harvard University from 1905 until 1929 is the Harvard University Press publication, the Quinquennial Catalogue (Harvard University 1930). This document, produced by Charles Williams Elliot and Abbott Lawrence Lowell reporting to the Board of Overseers, remains a remarkably detailed resource on all degree recipients from Harvard. The Harvard/Radcliffe Online Reference provides data for years 1930 to 1955. Thereafter, the recording of degree recipients is far less consistent from year to year and often does not provide the level of detail that would permit the researcher to identify the subfield of study.

This catalogue and online reference provides for each degree recipient the names, all recorded institutions attended and years of all recorded degrees. For each year, my able research assistants reviewed each doctoral degree awarded in the Department of Economics and extracted information on last, first and middle name; date of Ph.D. awarded; undergraduate and masters' degrees awarded, dates and location; dissertation title and dissertation advisor. The full spreadsheets with the collected information are available at the permanent link: www.hhh.umn.edu/centers/rwc. Also included in the link is a list of black Doctorates in Economics from Harvard University from 1957 to 2004, but without the detail provided in the 1905-1955 listings.

The research assistants classified doctoral recipients as "black" if the recipient attended a Historically Black College or University; if they were listed in the census as "negro" or if a search of their names in Ebony Magazine, Jet Magazine, New Amsterdam News, and Afro-American newspapers yielded results.

Several persons on the list were identified by survivors or from obituaries as African American. ${ }^{9}$ Researchers also attempted to match persons with "typically black names" with census lists and obituaries to rule out the possibility that persons with common African American names were mistakenly included or excluded.

\section{The First Six Negro Ph.D.'s in Economics from Harvard University}

Figure 1 reports the numbers of Ph.D.'s in economics awarded by Harvard University from the first degrees in 1905 to 1955, the last year when titles and names were regularly provided in annual reports. During its first 30 years, the department produced less than ten economics doctorates per year. This period roughly corresponds to the administration of President A. Lawrence Lowell (1909-1933). During this period there were no known African American Ph.D.'s in economics. The first Japanese Ph.D. was awarded in 1914 (collected data, Roy Wilkins Center). The first Chinese Ph.D. was awarded in 1920 (collected data, Roy Wilkins Center, see Trescott 2007). Overwhelmingly, the names of the recipients of economics doctorates from Harvard before 1933 were Anglo-Saxon names ${ }^{10}$ (Backhouse 2013; Greene 2011).

\footnotetext{
${ }^{9}$ This method of identification clearly leaves open the possibility that there are African American graduates who were not counted. However, the main criterion for identification is census designation and/or recognition as black in the major African American media.

${ }^{10}$ Seymour Harris received his Ph.D. from Harvard in 1926 and was the first tenured Jewish professor (Harris, Seymour Edwin, 1897-1974). Seymour Harris as first Jewish tenure professor in economics department (Seymour Edwin Harris, 1897-1975).
} 


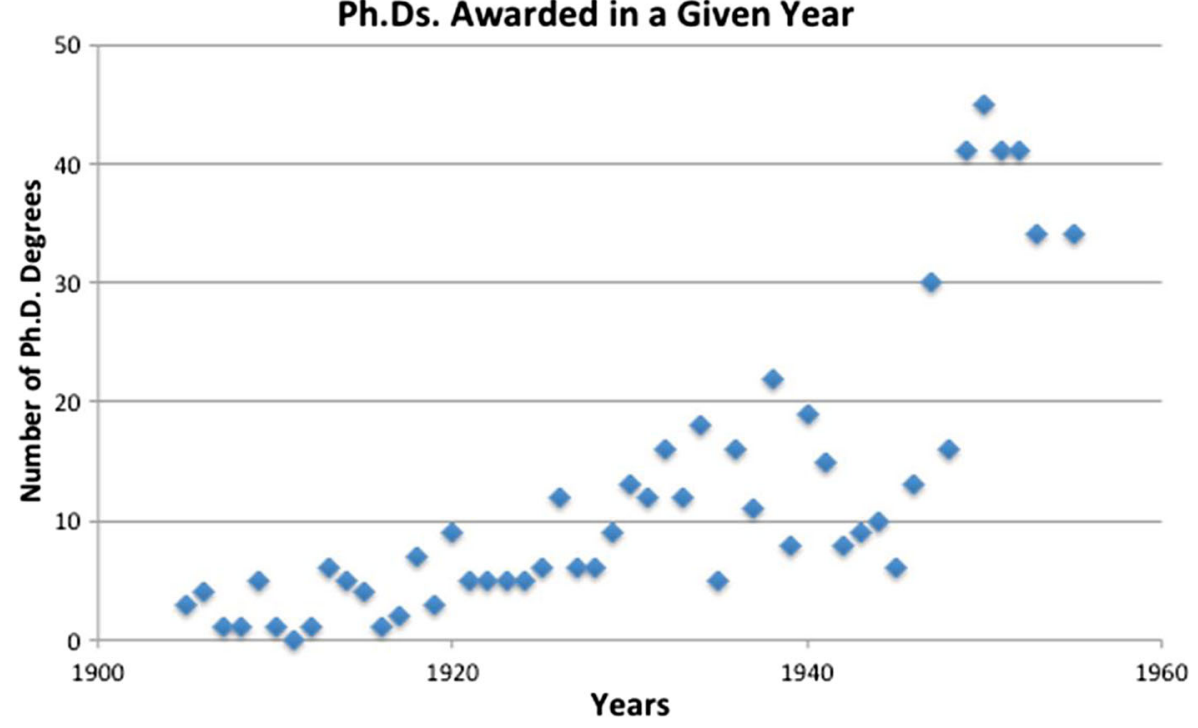

Source: Collected Data, Roy Wilkins Center.

Fig. 1 Harvard economics Ph.Ds. awarded, 1905-1955

From 1905 to 1933, the distribution of undergraduate degrees was skewed towards elite Ivy League and northeastern colleges. From 1933 forward, the distribution increasingly reflected a broader cross-section of institutions and students in the United States. Figure 2 shows, nonetheless, that Harvard College produced the largest number

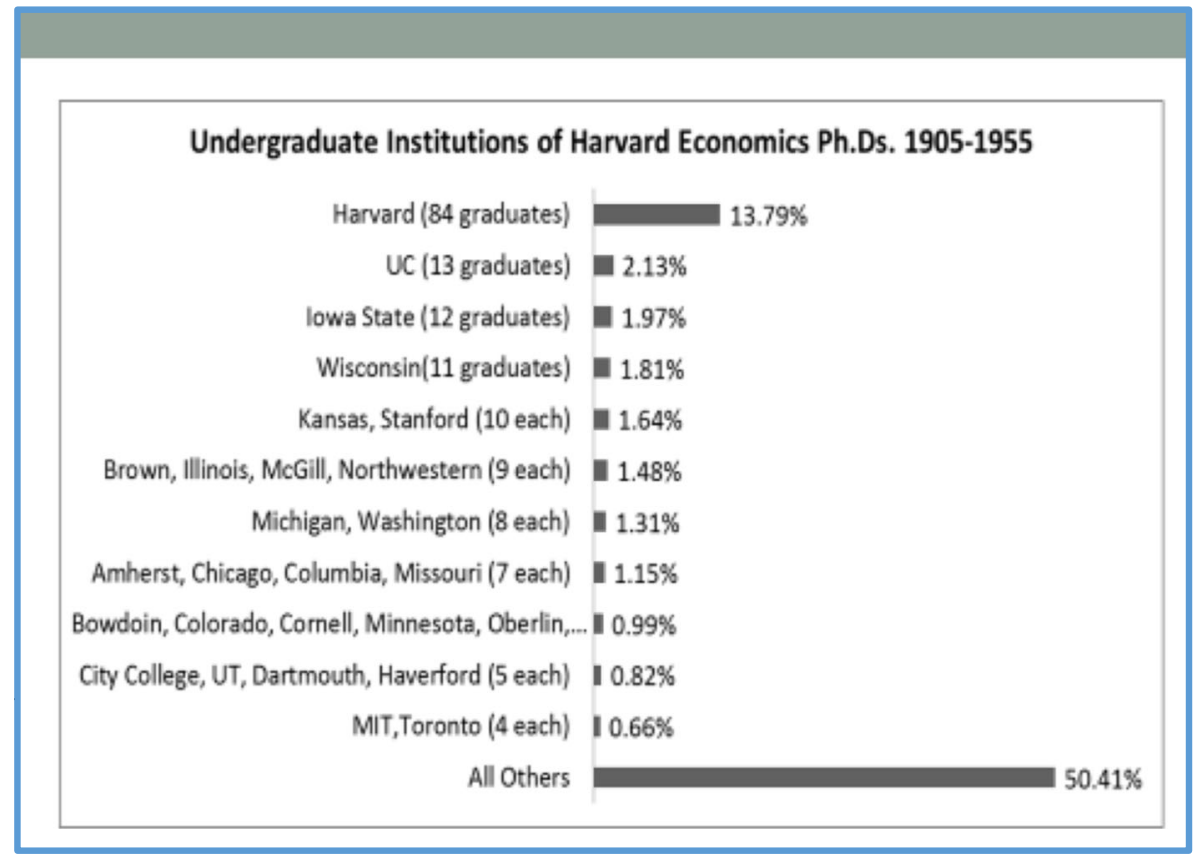

Fig. 2 Undergraduate institutions of Harvard economics Ph.Ds. 1905-1955 
of graduates during the entire period, representing almost $14 \%$ of all persons earning the doctorate in economics.

\section{Robert Clifton Weaver}

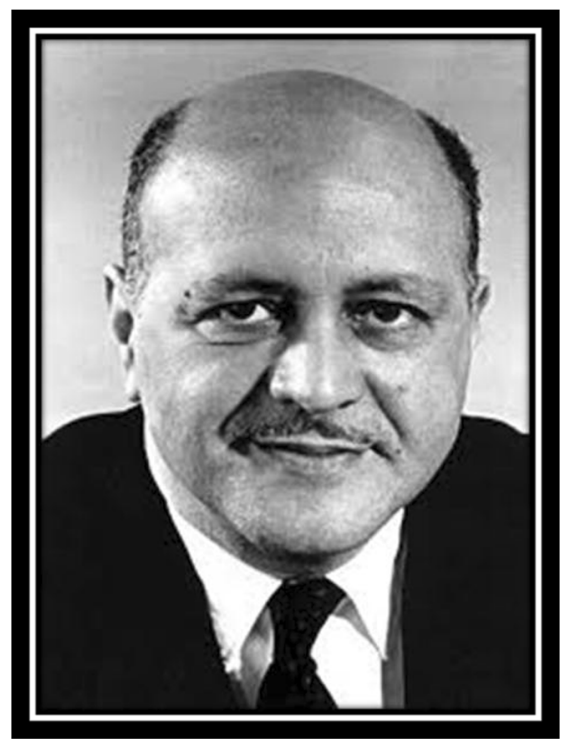

United State Department of Housing and Urban Development. Robert Clifton Weaver.jpg. Public Domain.

The first known African American to receive the Ph.D. in economics from Harvard University was Robert Clifton Weaver. At a time of segregation, Weaver attended Dunbar High School, the distinguished academic high school for blacks (Barron 1997). He went on to Harvard University, where he earned a Bachelor of Science and Master of Arts degree. He also earned a Ph.D. degree in economics in 1934 (Barron 1997).

Weaver's dissertation, "The High Wage Theory of Prosperity," examined the theoretical debates about consumption and savings in the US economy after the Great Depression (Pritchett 2010). Weaver developed alternative explanations for over-savings behavior throughout the business cycle (Weaver 1935). He argued that high wages would sustain economic stability by boosting consumption and augmenting industrial output. Weaver's theory and model support the argument that high wages are compatible with low real labor costs due to higher productivity of workers, yet increases in wages above a critical point could change factor proportions resulting in higher unemployment. Although mass production would result in lower consumer prices, Weaver argued that higher wages were necessary to prevent market disequilibrium with overproduction and under-consumption by low-income groups.

Weaver references two specific writers of the nineteenth Century to further the high wage theory in his dissertation. He cites Lord Lauderdale as the first theorist to argue the need to "maintain a balance between accumulation and consumption." (Weaver 1935) From Lauderdale, Weaver finds the necessary support for the potential problem of over-saving and applies it to the business 
cycle. Weaver cites Simonde de Sismondi as "one of the most stimulating authors of the early nineteenth century" and one of the first writers to theorize about the business cycle (Weaver 1935). Weaver builds upon both Sismondi and Lauderdale to conclude that "mass production requires mass consumption" requiring higher wages (Greene 1936; Weaver 1935, 2006; Wilson $2006^{11}$ ).

Weaver's dissertation adviser was William Z. Ripley, Professor of Political Economy at Harvard University (1902-33) (William Z. Ripley). Ripley was an engineering graduate of MIT (1890) and received his Ph.D. in economics from Columbia in 1893 (Professor Ripley of Harvard Dies 1941). He was a lecturer in sociology at Columbia University from 1895 to 1901 (William Z. Ripley). Weaver was an active leader in the American Economic Association, having served as its vice president from 1898 to 1901 and its elected president in 1933 (William Z. Ripley), the year that Weaver was completing his dissertation.

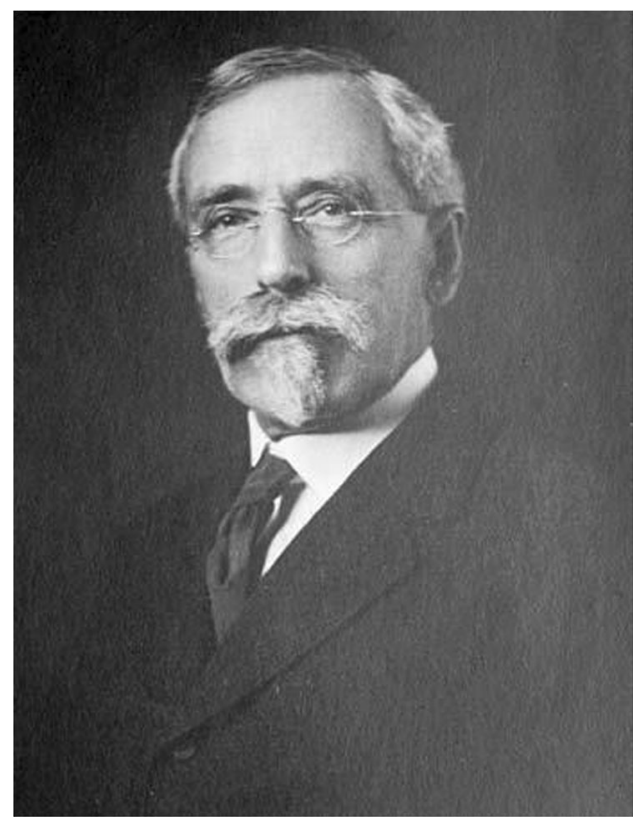

Encyclopedia Britannica. William Ripley. Jpg, nd. http://www.britannica.com/biography/W-Z-Ripley

Ripley (1899) is best known for his book, Races of Europe, in which he argued that race is the central engine to understanding human history. His tripartite theory of races divided Europeans into three racial types: Teutonic, Alpine (Celtic), and Mediterranean. Ripley's tripartite system was championed

${ }^{11}$ See Robert Weaver's dissertation "The High Wage Theory of Prosperity," in Wilson (2006). 
by Madison Grant, who changed Ripley's "Teutonic" type into his own Nordic type, which he postulated as a master race, as the key social group responsible for human development (Grant 1916). Grant's Nordic Theory further advocated the separation, quarantine, and eventual elimination of "undesirable" traits and "worthless race types" from the human gene pool and the promotion, spread, and eventual restoration of desirable characteristics and "worthwhile race types" conducive to Nordic society. His book was the basis for the master race theory of Adolf Hitler, who sent a letter to Grant saying, "This book is my Bible." (Black 2004)

Later in life in the 1920's, Ripley rose as a vocal critic of the old railroad system (Ripley 2000) and the practices of large corporations on Wall Street (Ripley 1929). Before the stock market crash of 1929, which he was credited for predicting, Ripley was nearly killed in an automobile crash after testifying against big corporations, and he subsequently suffered a mental breakdown (Williamson 1929). Ripley was absent from the Economics Department during much of the time when Weaver was in residence at Harvard. It is unknown how these events affected his relationship with Weaver and Ripley's subsequent departure from the Economics Department. Ripley suffered a subsequent mental breakdown in 1933 and retired from Harvard.

Robert Weaver, however, went on to a lead a successful career in the public sector. He was among the inner-circle that provided advice to Franklin Delano Roosevelt in what was once called the "Negro Cabinet."12 In 1960, after serving as the New York State Rent Commissioner, Dr. Weaver became the national chairman of the National Association for the Advancement of Colored People, and President Kennedy sought Weaver's advice on civil rights (Barron 1997). In 1961, Kennedy appointed him as the Administrator of the Housing and Home Finance Agency (HHFA), the highest federal appointment then assigned to any African American (Armstrong and Pendergast 2005). Kennedy's failed attempt to raise the agency to Cabinet rank was successfully pushed by President Johnson in 1966, and Weaver became the head of the US Department of Housing and Urban Development (HUD), becoming the first African American to serve in a Presidential Cabinet (Armstrong and Pendergast 2005). Weaver left the government in 1969 to become President of Baruch College and, from 1970 to 1978, he was a Professor of Urban Affairs at Hunter College. His other publications include The Urban Complex (Weaver 1964) and Dilemmas of Urban America (Weaver 1965) (Armstrong and Pendergast 2005).

\footnotetext{
${ }^{12}$ President Franklin D. Roosevelt appointed an unprecedented number of African Americans to high positions. By mid-1935, forty-five African Americans had positions in cabinet offices and New Deal agencies. In 1936, this group began calling itself the Federal Council on Negro Affairs. Although these leaders were not officially cabinet members, their role in advising the President on black employment, education, and civil rights issues led the press to refer to them as FDR's "Black Cabinet." Among them was Robert C. Weaver, who served as a Special Assistant to the Administrator of the United States Housing Authority (The Black Cabinet).
} 


\section{William Henry Dean, Jr.}

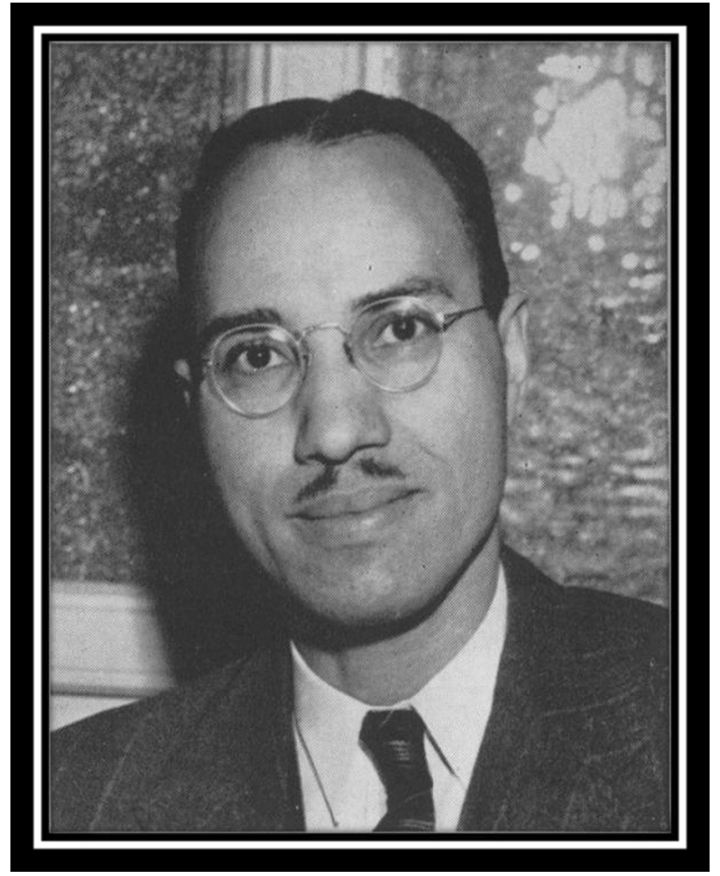

Journal of the National Medical Association. (Dr. William Henry Dean 1952).

The second known black Ph.D. in economics from Harvard was William Henry Dean, Jr. A contemporary of Weaver, Dean attended Frederick Douglass High School in Baltimore, Maryland (Dean, William H. (1910-1952)). His father was a prominent clergyman and leader of civic organizations in Baltimore (Brewer 1953). The principal at Douglass High School was Mason A. Hawkins, who had obtained an AB from the historically black, Morgan College; a second AB from Harvard University; Master's degrees from Harvard and Columbia Universities; and then ultimately wrote a dissertation on education of the Negro and received his Doctorate in Education from the University of Pennsylvania (Mason Albert Hawkins, Ph.D.). Mason Hawkins, who later taught economics at Morgan College, played an influential role in securing financial support for Dean to attend Bowdoin College (Mason Albert Hawkins, Ph.D.). Delta Lambda chapter of Alpha Phi Alpha Fraternity provided one such scholarship enabling Dean to attend Bowdoin (Dean, William H. (1910-1952)). Dean excelled at Bowdoin graduating summa cum laude, Phi Beta Kappa and was the valedictorian of his class in 1930. At Harvard, he was a university scholar (193031), Henry Lee Memorial Fellow (1931-32), and Edward Austin fellow (1932-33). He received his Master's in economics in 1932 and his Ph.D. in economics in 1938 from Harvard. A close classmate of Paul A. Samuelson (Ellison 1991), the first American winner of the Nobel Prize in economics, Dean successfully published his doctoral dissertation, "The Theory of the Geographic Location of Economic Activities, with special reference to Historical Change," which was used as a text in economics courses at Harvard and Northwestern University (Appiah and Gates 2005). This text was 
widely quoted in leading theoretical journals in the emerging field of location economics. ${ }^{13}$ Dean's contribution to location theory is evident in a pioneering Econometrica article by Walter Isard, ${ }^{14}$ whose first doctoral student in Regional Science was William Alonso, known as the father of urban economics (Capello and Nijkamp 2004). In his 1952 Econometrica article, Isard adopted Dean's core analytical apparatus and extended the model to include transportation costs in a continuous space economy where the distance to markets affects producer profit functions. (Isard 1952).

Dean's life came to a tragic end when he committed suicide in New York City in 1952 following his teaching assignments at Atlanta University (1933-1942) and research posts at the United Nations as the chief of the United Nations Africa Unit Division of Economic Stability and Development (Dean, William H. (1910-1952)).

The tragedy of Dean's life is underscored by the fact that he was considered the very top student in the Economics Department at Harvard. A letter from the Department chair, regarding Dean's winning the Henry Lee fellowship, attests to the high regard his advisors at Harvard held for Dean. Also evident from the files is the fact that as an economic theorist, Dean was unable to secure employment at any of the major research universities that regularly hire economic theorists. For example, in his letter to the City College of New York, Harvard Professor Charles Bullock points out that:

In the Graduate School of Arts and Sciences at Harvard University we have a very remarkable colored student...I believe I am making a very conservative statement when I say that in point of natural ability and scholarly accomplishment up to date, he is entitled to be ranked among the three or four most distinguished colored students that we have ever sent out from Harvard College or from the Graduate School of Arts and Sciences.

I may add...that the present chair of the Department of Economics, Professor H. H. Burbank, who is better acquainted with this student's work than anyone else on the ground, fully agrees with the views that I have expressed above and in the memorandum.

In Ralph Bunche's eulogy written in the New York Times, and the Chicago Defender, the following describes Dean's genius:

He had done excellent work on previous commissions for the UN...He had led a mission of six experts throughout Italian Somaliland, now under United Nations trusteeship, to survey means of making the primitive country self-supporting...Dean had been a brilliant scholar, and had made

\footnotetext{
${ }^{13}$ One of the most prominent articles that cites Dean's dissertation is by Douglas C. North (1955).

${ }^{14}$ Walter Isard is the founder of the field of regional science and one of the most prominent scholars in industrial location theory. He established the Journal of Regional Science and set up regional science departments at MIT and at the University of Pennsylvania, where the first Ph.D. was awarded to William Alonso for his seminal study of urban location and land use (see http://www.cerum.umu.se/digitalAssets/57 157525 isard-obituary.pdf).
} 
an excellent record as college professor, sociologist, Government aide and since 1946 a specialist for the United Nations (Dr. Wm. Dean, Former A. U. Professor Found Dead in N.Y. 1952, January 10).

Nonetheless, the archives show that the Department of Economics at the time was only willing to recommend Dean for a position at a "colored" college, despite his apparent stellar achievements as the top student in the Department.

Charles J. Bullock, a Professor of Economics at Harvard, was an appointed chairman of the Harvard University Committee on Economic Research from 1917. He is the author of an extensive list of books and essays on the elements of economics and public finance. He wrote:

In the fall of that year, he came to Harvard to pursue graduate study in economics; and made such a brilliant record in courses of study, and such a favorable impression upon his instructors, that in the spring of 1931 he was awarded by the Department our Henry Lee Fellowship in Economics, which is the highest honor the Department has at its disposal.... The Henry Lee Fellowship is seldom if ever renewed; but another fellowship, paying nearly as much, which was the best the Department of Economics could bestow upon a man who had just held the Henry Lee Fellowship, was awarded Mr. Dean by a unanimous vote in the spring of 1932. In the discussion preceding the vote, no other of our graduate students was seriously considered in competition for this second appointment.

This glowing set of accolades is dimmed by the following limiting assessment about the job prospects of Dean:

Not only is Mr. Dean a student of brilliant attainments and unusual intellectual capacity, but also he is also a man of good presence, attractive personality, and apparently equipped in every way for scholarly pursuits and the vocation of a teacher of economics ..... He wants to be a teacher of economics; and I am confident that the record that he has made here and his attractive personality and excellent qualifications for work in higher educational institutions will interest anyone who may be looking for an instructor in economics, or economics and related subjects, in any academy, school, college, or university devoted to the education of colored students in the United States.

The 1932 letter is reproduced in its entirety to illustrate the paradox of Dean being their best candidate but their unwillingness or inability to place him in a major-group institution.

In his doctoral dissertation, Dean experimented with analogies drawn from the physical sciences and mathematics to analyze resource allocation decisions. ${ }^{15}$ The central contribution of Dean's doctoral dissertation to the field of economic location theory is its applied mathematical models and analysis methods of celestial mechanics to the problems of economic analysis. His published book, based on his dissertation,

\footnotetext{
$\overline{15}$ The discussion summarizing major focuses of Dean's dissertation is from Ellison (1991).
} 
HARVARD UNIVERSITY

DEPARTMENT OF ECONOMICS

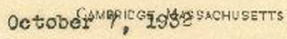

To Whom It Hay Concern:

The subject of this memorandum, Mr. Milliem

Henry Dean, Jx. is a graduate of Bowcioin College where he received the baohelor'a degree in 1930. In the rall of that year he came to Harvard to pursue graduate study in economios; and made such a brillient reoord in courses of study, and such a farorablo impression upon his instructors, that in the spring of 1931 he was awarded by the Department our Henry Lee Fellowship in Economics, which is the highest honor the Department has at 1 ts disposal. This Fellowship was never before awarded to a colored student. We have not had many aolored mon among our graduate students in eoonomios; and few if any of them have ever been of fellowship grade. Irr. Dean's record and the impression that he made upon his instruetors were so excellent that he vrs without any question awaxded the Fellowship.

That this very high distinetion achieved by Wr. Dean in the spring of 1931 wes thoroughly justified was abundantly shown by the reoord which he made in the academic year 19311932. The Henry Loo Fellowship is seldom if over renewed; but another fellowship, paying nearly as much, which was the best the Deportmont of Beonomico could beetow upon a man who had just heid the Fenry lee Fellowshlp, was awarded lfr. Dean by a unaninous vote in the spring of 1932. In the discussion preceding the vote, no other of our graduate students was seriously oonsidered in competition for this second appointment.

Not only is Hir. Dean a student of briliziont attainments and unusual intellectual capacity, but he is also a man of good presence, attractive personality, and apparently equipped in every way for scholarly pursuits and the vocation of a teacher of economios and such allied subjects as an instruetor or professor of economics is sometimes required to handle in the olassmroom. $\mathrm{H}_{\theta}$ is a young man who thoroughly understands himsolf and his work. His head has not been turned in the least by tho distinguished suoeess he has achieved here; on the contrary, he is a very modest person who isn't thinking about what he has accomplished but of the work that lies ahead. Ho wants to be a teacher of econonies: and I am confident that the record that he has made here and his attractive personality and excellent qualifications for work in higher educetional institutions will interest any one who may be looking for an instructor in economias, or economics 
and related subjects, in any acaderny, school, college, or university deroted to the education of colored students in the United States.

I have conferred with Prafessor $\mathrm{H}$. $\mathrm{F}$. Burbank, the Chairnan of the Department of Economics at Harvard University (who may be addressed at 41 Holyolce House), who will, if desired, confirm any statement that I have made. He considers Nir. Dean one of our most ronarkable students, and vill be glac to do anything that lies in his power to help him secure such a position as his merits entitle hin to receive. 3ir. Dean's address in Cambridge is 22 a Conent Fall, and his home address is 2606 Centre Avenue, Pittsburgh, Pennsylvania.

If either Professor Burbank or I can give you any further information or expression of opinion on sny points not covered by this letter, wa shall be very glad indeed to do so. We consider phr. Dean such a remarkable man that we should be doing less than our duty if we did not take steps to bring his name early in the present academic year to the attention of people interested in the welfare of institutions of higher education for colored people in the United States.

If recipients of this letter do not happen themselves to know of opportunitios, but can either pass this nemorancun along to persons who may have such information or send us the names of such persons, so that we may send them copies of the memorandum, we should be very glad indeed to have tham do so.

Yours very truly,

$$
\begin{aligned}
& \text { charen } 6 \text { obuckon } \\
& \text { Probunw o Earemein }
\end{aligned}
$$




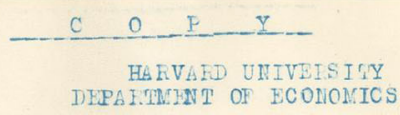

Cembridge, Massachusett.s.

October $7,1932$.

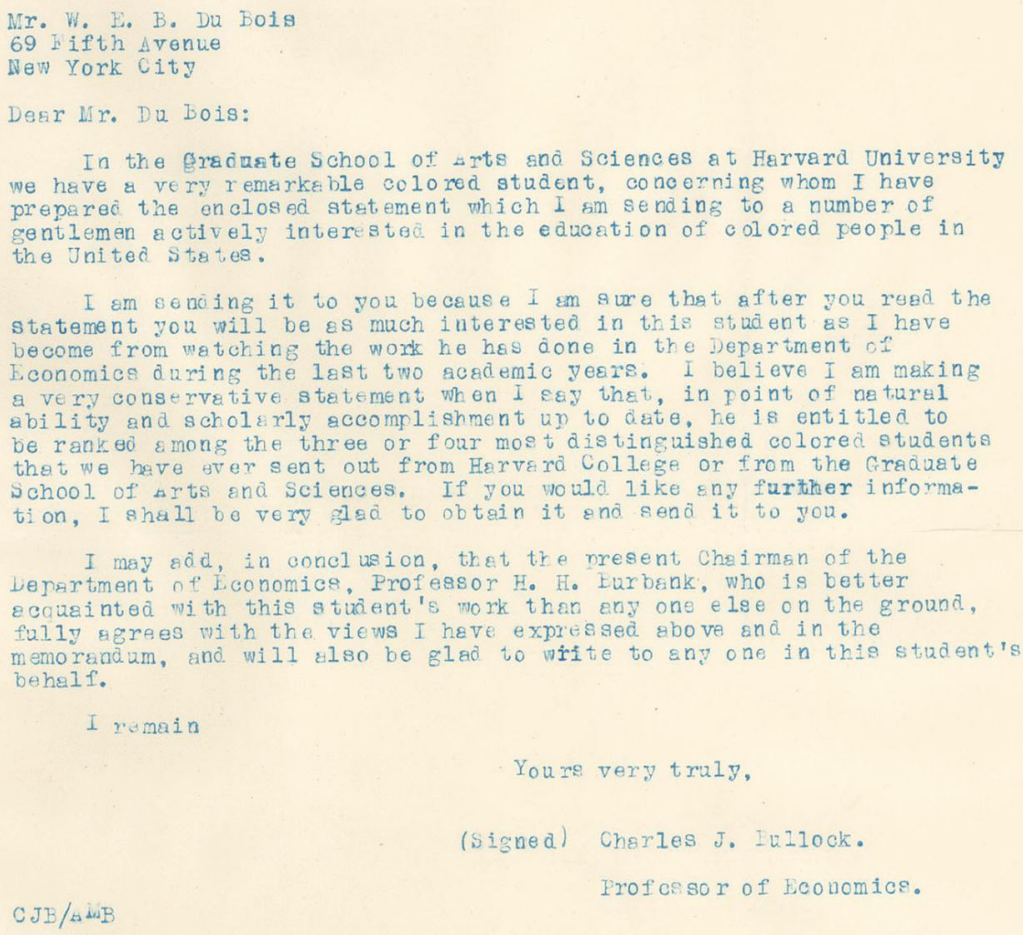

illustrated the relationship between location theory and celestial mechanics. In his analysis, Dean constructed a locational triangle and a weight triangle, which displayed the relationships among sites of input sources, production, and the market. He predicted that the locations of each of these sites was "determined by analogy to the laws of gravity and celestial motion of Isaac Newton (1946), Lagrange, Poincaré (1957, 1905-10, 1912), and Birkhoff." (Ellison 1991 p. 316)

Before 1950, Dean, along with Paul Samuelson, was among the few economists who cited the work of physical scientists and mathematicians in their analysis. He was a pioneer in experimenting with the analytic techniques in economics. His analysis predicted the source of "gravity or potential models in location theory developed beginning in in the late 1940s by" prominent scholars such as "John Stewart (1948) and others." (Ellison 1991 p. 317)

Dean's dissertation advisor was the famed economic historian Abbott Payson Usher, after whom one of the highest awards in economic history is named (The Abbott Payson Usher Prize). Born in Lynn, Massachusetts, Usher took all his academic degrees 
at Harvard (Usher, Abbott P.). After receiving his Bachelor's degree in 1904 and Master's degree in 1905, Usher spent a year in France, studying and gathering data for his work on early grain markets (Usher, Abbott P.). He received his Doctorate in 1910 and acquired an appointment at Cornell University, where he taught for ten years (Usher, Abbott P.). In 1922, he was appointed to the faculty at Harvard, where he taught economics until his retirement in 1949 (Usher, Abbott P.). Usher's contributions to the scientific inquiry of economic history include his book, A History of Mechanical Inventions, in which he argues that innovation is a slow process by many contributing inventors and not a product of a single genius (Molella 2005). Dean's dissertation clearly shows the influence of Usher (2011), who combined economic history and technological advances.

\section{Booker Tanner McGraw}

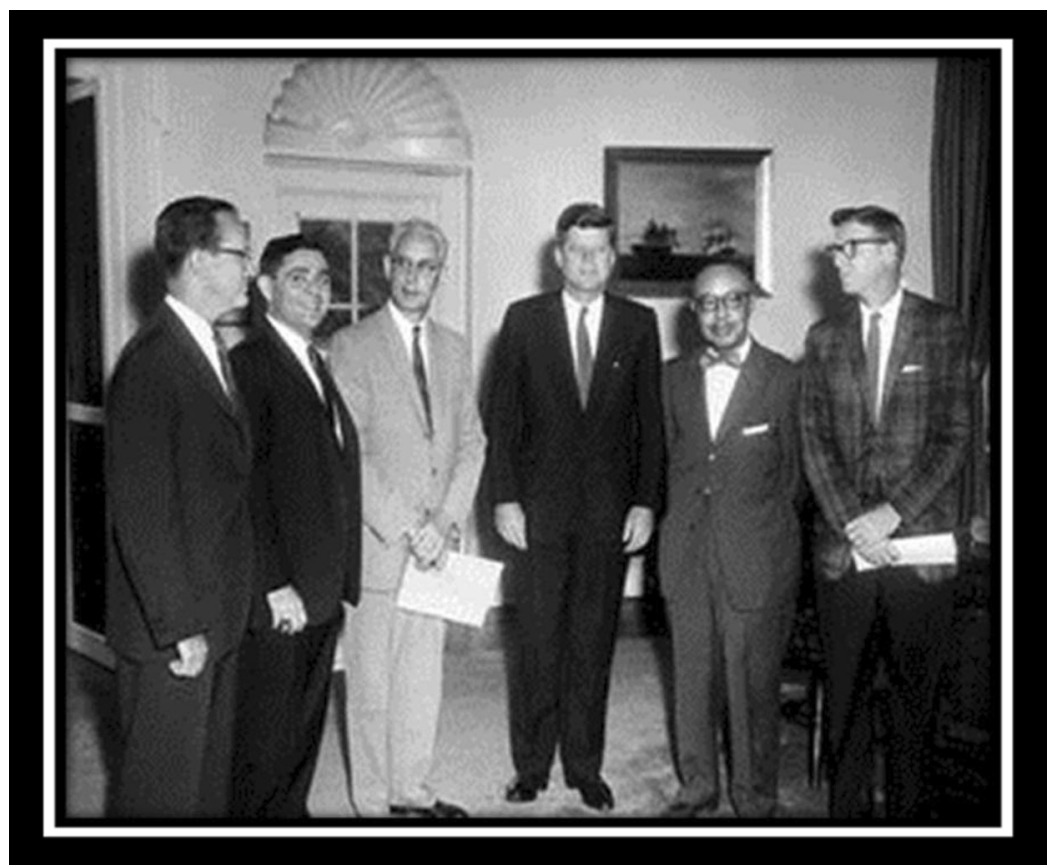

White house photographs. Booker Tanner McGraw. jpg, $1961 .^{16}$

In the same cohort as Weaver and Dean, Booker T. McGraw was the third black to receive a Doctorate in Economics from Harvard. His doctoral dissertation was on French monetary policy (Harvard/Radcliffe on-line historical reference shelf: Annual reports). Although McGraw obtained his Master's degree in the same year as Dean and earned his Doctorate the year after Dean (Harvard/Radcliffe on-line historical reference shelf: Annual reports), McGraw had graduated from undergraduate school at least a half dozen years before Dean and Weaver (Harvard/Radcliffe on-line historical

\footnotetext{
${ }^{16}$ Photograph by Rowe, Abbie (1961) AR6756-A. President John F. Kennedy Meets with Delegation from National Association of Intergroup Relations Officials (NAIRO) http://www.jfklibrary.org/AssetViewer/Archives/JFKWHP-1961-08-23-B.aspx
} 
reference shelf: Annual reports). McGraw, a graduate of Atlanta University, obtained his MA and MBA from the University of Michigan in 1923 and 1924, respectively. ${ }^{17}$ He served as the head of the Economics and Finance Department of Lincoln University (Missouri) from 1924 to $1942,{ }^{18}$ where he taught economics to Constance Simms, the aunt of former NEA President and RBPE Editor, Dr. Margaret Simms. ${ }^{19}$

Following his post at Lincoln University, McGraw worked as a minority housing consultant during World War II (McHugh 1968). McGraw collaborated with several government agencies to help unemployed Negroes fill vacant jobs and locate homes (McHugh 1968). This experience resulted in McGraw becoming Assistant to the Administrator, Housing and Home Finance Agency, from 1961 to 1963 under the leadership of Robert Weaver (The Sphinx 1955). McGraw was instrumental in Weaver's nomination as head of the housing agency and the passage of the post-war housing act (McHugh 1968).

McGraw provided these comments on Weaver being selected the Head of the Housing Agency:

Well, Louis Martin was the approximate person who got this done, working with Bobby [Robert F. Kennedy] and Jack, but confidentially Louis and I had been working on that as soon as Louis joined as talent scout and we talked this thing over. I don't know that Bob Weaver today knows how my hand was in there. After all, I had no business - it wasn't a political thing with me, but it was one of these businesses of trying to identify talent and get it where it can serve best, which we've always done, which we consider part of our job, and I have no apologies to make for it.

I don't know who else [was considered]...But Louis and I know, both knew that there was no more qualified guy for the job than Bob. It was just a matter of whether the Kennedys had enough starch in their backbone to override tradition, go ahead and give it back to the best qualified man, who happened to be a Negro, and take full advantage of breaking new ground. (McHugh 1968)

McGraw's doctoral dissertation was a study of French Monetary Policy between the year 1927 and 1938, when the Poincaré de facto stabilization of the French franc took place (The University 1939. See pp. 199-203 for Booker Tanner McGraw's French Monetary Policy, 1927-1938). He examines the franc experience to illustrate the consequences of misapplication of conventional economic theory to monetary policy. The dissertation highlights the limitations of pure monetary theory in achieving economic stability and underscores the importance of basic institutional instruments and arrangements. The dissertation covers the franc stabilization policy (1926-1928) and the resulting economic expansion; a transition period of the franc during which gold imports flowed into the country in unprecedented volumes (1928-1932); The dissertation probes the French "New Deal" program, which was designed to increase consumer purchasing power. McGraw examines the period following the devaluation of franc, exploring the ensuing problems, processes, and consequences.

\footnotetext{
17 "LexisNexis Academic," accessed March 16, 2016, www.lexisnexis.com.ezp2.lib.umn. edu/hottopics/Inacademic/

18 Ibid.

${ }^{19}$ Personal Interview with Margaret Simms, March 2014.
} 
It is not clear who McGraw's dissertation advisor was. The signature on the photocopy of his dissertation archived in the Harvard Libraries is not decipherable. But, a review of all 50 Harvard Ph.D.'s in economics awarded between 1938 and 1940, reveals that only four others were on banking or monetary policy: Walter Whitmore Chadbourne's “A History of Banking in Maine, 1799-1930;” Mark Keith Inman's "Experience in Canadian Banking, 1929-1934;" Wolfgang Friedrich Stolper's "British Monetary Policy and the Housing Boom, 1931-1935;" and Yuan-Chao Wagner, "German Exchange Control, 1931-1936." Samuel Myers, Sr., in oral interviews, asserts that graduate students in Money and Banking were among the most prized students (after those in econometrics and theory) with many, if not most, supervised by Alvin Hanson and John Henry Williams.

\section{Hastings Dudley Huggins}

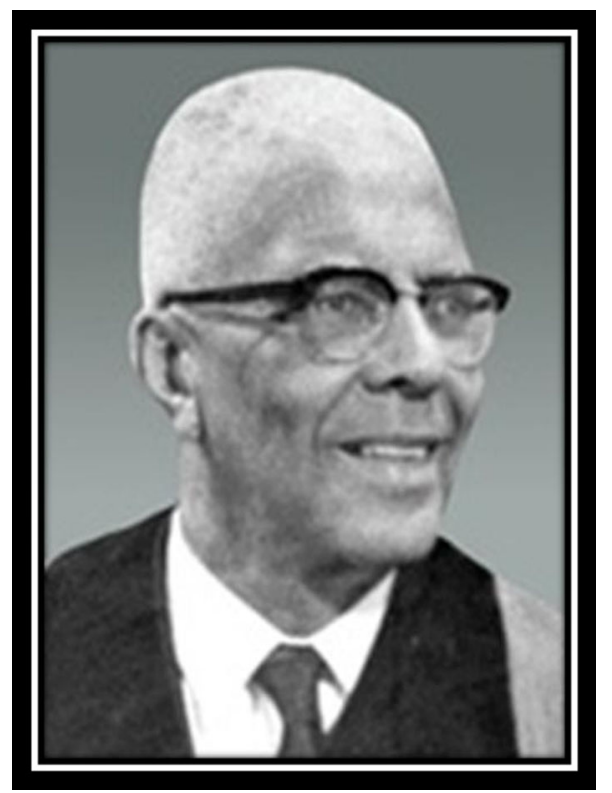

The University of the West Indies. Sir Dudley Huggins. ${ }^{20}$

The fourth black to receive the Ph.D. in economics from Harvard University was Hastings Dudley Huggins. Huggins was born into a wealthy family of landowners in Nevis, West Indies. He attended private boarding schools, graduated from the West Indian Agricultural College in 1926 with a degree in agricultural economics and worked as an economist for the Department of Agriculture in British Guiana (Leaver 2010). He traveled widely, excelled in sports, and was noted for his love of poetry and literature. He won a scholarship to Cornell University, completed a Master of Science in Agricultural Economics and returned to British Guinea. He contacted John D. Black in 1945 and requested admission

20 "Office of the Campus Principal." The University of the West Indies. Accessed March 16, 2016. https://sta. uwi.edu/principal/pastprincipals.asp. 
to the Ph.D. program in economics at Harvard University at the age of 41 . He completed his oral exams and his dissertation in two years and was awarded his Doctorate in 1947.

Huggins was a pioneer in studying the agricultural economy of the British Caribbean. His 1947 doctoral dissertation, "The economic research program of British Guiana, 193345," was based on the series of projects funded by the British Guinea Department of Agriculture (Huggins 1947). The projects consisted of studies on the price, wage movements, and fertilizers in British Guinea between 1910 and 1932, seasonal variation in prices and exports of agricultural products from 1922 to 1932. Other projects were economic studies of small-farming areas, marketing of certain minor agricultural products, rice producing farms, dairy-farming, and a comprehensive irrigation-drainage program in British Guinea. Huggins' studies were closely aligned with the research interests of John D. Black, the founder of the Applied Economics Department at the University of Minnesota.

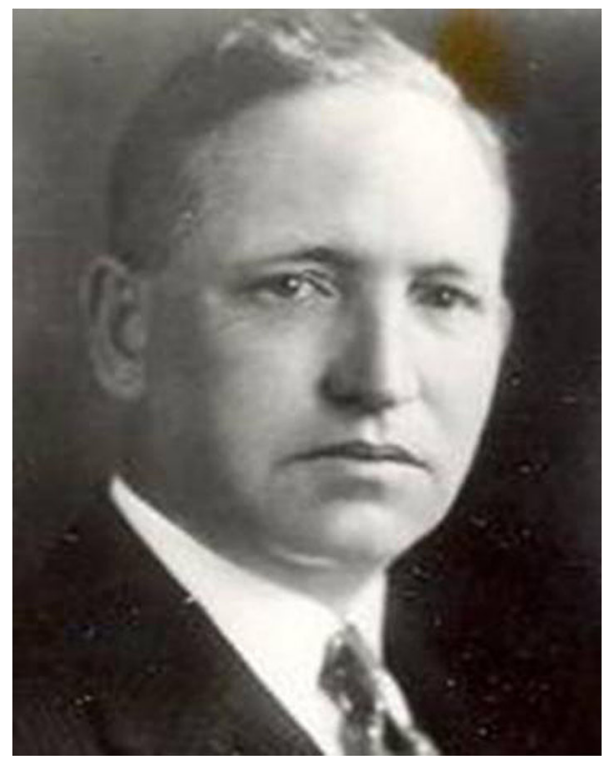

John D. Black

Memoir of a West Indian's Journey. John D. Black. jpg (Chapter 5 in Leaver 2010).

Huggins served as the first Director of the Institute of Social and Economic Research, from 1948 to 1963 (Dudley Huggins papers SC9). In 1963, he was appointed Pro-Vice Chancellor of the St. Augustine campus of the University of West Indies, Trinidad and Tobago, where he served until his retirement in 1969 (Dudley Huggins papers SC9). He died in of lung cancer after leaving the West Indies during the years of student protests.

Huggins' mentor and dissertation advisor was John D. Black. Black was born in a log cabin and grew up in rural Wisconsin (Cochrane 1989). He attended the University of Wisconsin, earning his Bachelor and Master's degrees in English. In order to support his siblings, Black taught English literature at the School of Mines in Michigan before returning to Wisconsin to earn his Doctorate in agricultural economics in 1919 at the age of 36, studying under John R. Commons (John D. Black). He was a Professor of Agricultural Economics at the University of Minnesota from 1918 to 1927 and chief of 
the Division of Agricultural Economics. He was the first director of Department of Applied Economics at University of Minnesota.

In his 1926 book, Introduction to Production Economics, Black anticipated many of the key developments in modern economic theories of production, laying the foundation for production theory taught throughout the world. In 1927, he joined the faculty at Harvard University and became increasingly involved in the field of agricultural policy, serving as one of the authors of the Agricultural Adjustment Act of 1933.

In Huggins' memoir, written by his daughter Anne Huggins-Leaver, John D. Black is remembered as having secured research funds and grants to attract students from farm backgrounds who might not otherwise have been able to afford Harvard (Leaver 2010). He also generously and energetically promoted the careers of his former students. Huggins was not an exception, as John D. Black enthusiastically greeted him and introduced him to agricultural leaders in the USA and England (Leaver 2010). As a professor at Harvard, Black attracted many graduate students who wanted to study with him (Cochrane 1989). Of the 120 students granted fellowships by the Social Science Research Council to study agricultural economics, 45 came to Harvard to study with Black (Cochrane 1989). "Black's boys" was a term used with envy to refer to students who were well-financed through Black's phenomenal fundraising (Cochrane 1989).

\section{Samuel Lloyd Myers, Sr.}

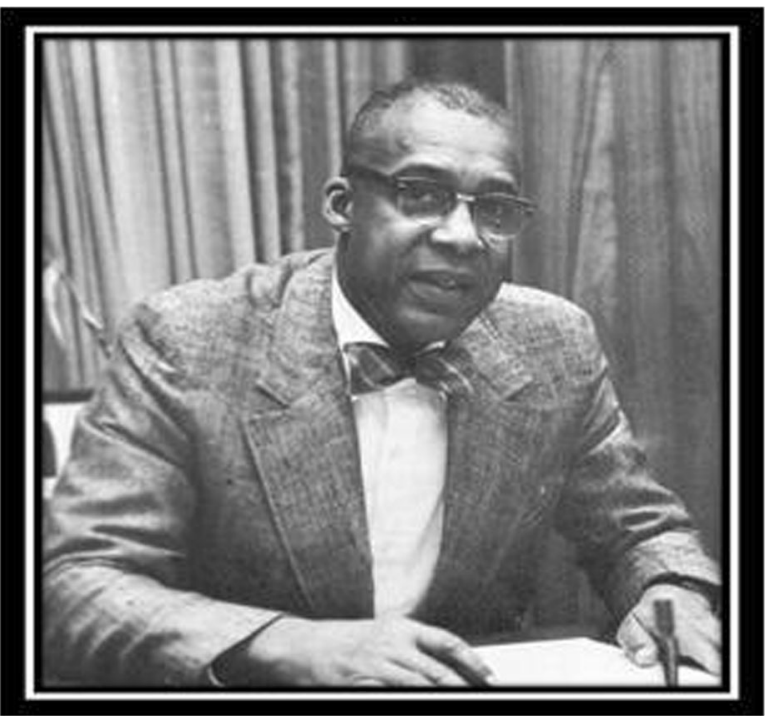

Bowie State University. Samuel L. Myers Sr. .pg $^{21}$

The fifth black to receive his Ph.D. in economics from Harvard University is my father. Samuel L. Myers, Sr. was born to Jamaican immigrants in Baltimore, Maryland. His mother washed and ironed shirts for white families; his father, who had immigrated to

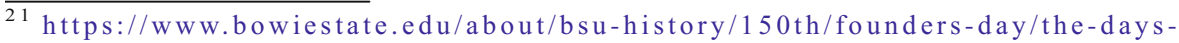
events/convocation/presidential-profiles/
} 
the United States in 1906 to study engineering at Hampton Institute, worked most of his life as a ship steward after lack of funds forced him to drop out of college. Samuel Myers grew up in an impoverished section of the inner-city, but excelled at Frederick Douglass High School, graduating as the class salutatorian. After spending a year working as a mess-boy on a steamer ship, he vowed to major in economics to combat the abject poverty he saw in his travels to Calcutta. He matriculated at Morgan State, where he studied under Dr. Winifred O. Bryson, who received his Doctorate in Economics from the University of Pennsylvania (Samuel Myers 2003).

Other faculty included Mason Hawkins, the former principal at Douglass High School, who had attended Harvard in 1901. After graduating from Morgan at the top of his class in 1940, Myers was accepted into the Ph.D. program at Boston University and was hired as a research assistant to the department chair, Charles Phillips Huse, himself a graduate of Harvard's Ph.D. program in economics. Huse, who received his BA, MA and Ph.D. (1907) from Harvard, wrote the Financial History of Boston, 18221859 and had a special interest in consumer cooperatives.

In the introduction to his Boston University Master's thesis, Consumer's Cooperation: A Plan for the Negro (Myers 1942), Myers argued for the need for African Americans to embrace a cooperative system. Capitalism, Dr. Myers argued, exploited rather than benefited African Americans. The solution, he contended, was the formation of consumer cooperatives. The roots of the Negro consumer cooperative movement can be found in the writings of other black intellectuals and leaders, including W.E.B. Dubois (DeMarco 1974), A. Phillip Randolph and Marcus Garvey.

Jessica Nembhard, professor of Community Justice and Social Economic Development in the Department of Africana Studies at the City University of New York, authored Collective Courage: A History of African American Cooperative Economic Thought and Practice. Similar to Myers' thesis, Nembhard stressed the importance of cooperative economies for blacks throughout American history. This history can be traced to the origins of the black cooperative movement during slavery. Like Nembhard's analysis that seeks to convince African Americans to embrace the cooperative economic systems, Myers' Master's thesis builds an understanding of and foundation for consumer cooperatives among African Americans.

After receiving nearly all A's in his coursework at Boston University, Myers was accepted into the Ph.D. program at Harvard armed with stellar letters of recommendation from his advisers at Boston University. He began the core theory classes at Harvard in the summer of 1942, five months after the United States entered World War II. He was drafted into the Army, sent to Officer Candidate School, where he served with Edward Brooke, a classmate from Boston University, served in the Pacific Theatre and was discharged at the end of the war with the rank of Captain.

Myers (1949) wrote his doctoral dissertation on product labeling and testing. His work, "Product Testing and Labeling with special Reference to Textiles," discussed the nature of modern product labeling and problems arising from testing in the analysis of labeling. According to Myers, the testing of products had been established as the basis for labels to guide consumer choice. He pointed out, however, that the extensive testing necessary for product labeling had not yet become fully developed. He identified some of the challenges that arise from testing products, such as the technological problems in laboratory setting, as well as the difficulties of setting minimum standards for consumer goods. He also discussed in detail the specific forms of product labeling such as specification labeling, 
grade labeling, or informative labeling. The dissertation laid out an economic framework for understanding the information asymmetries associated with products of uncertain quality. The economic model of labeling is illustrated using original price and quality data collected from department stores in New York. The results were published in the American Marketing Association's journal and Extension Service Working Papers.

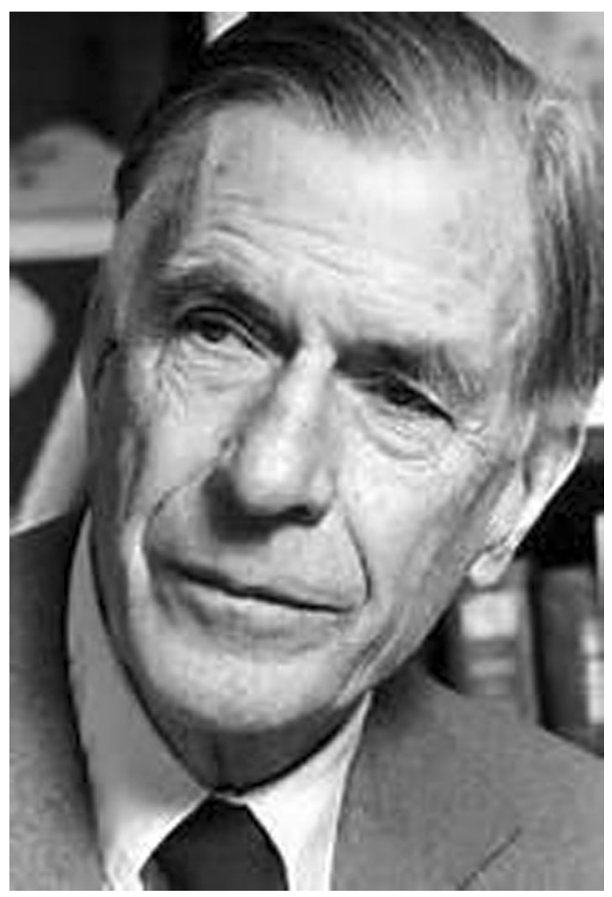

John K. Galbraith

Shema-root.org. John Kenneth Galbraith. jpg ${ }^{22}$

Myers' dissertation advisor was John Kenneth Galbraith. Galbraith received his Ph.D. in Agricultural Economics from the University of California, Berkeley in 1934 and was brought to Harvard University by John D. Black. Galbraith served as an untenured instructor at Harvard from 1934 to 1939. He was the editor of Fortune Magazine. With Eleanor Roosevelt and future senator and vice president Hubert $\mathrm{H}$. Humphrey, he founded the Americans for Democratic Action (ADA) in 1947. It was not until 1949 that Galbraith was appointed to a tenure-track position at Harvard University, after considerable maneuvering by John D. Black. According to Samuel Myers, it was Black who suggested to Galbraith that the newly appointed tenure-track faculty member supervise Myers' dissertation. John D. Black wrote to the Rosenwald Foundation and helped obtain support for Myers' project. As it were, Myers was among the last recipients of a Rosenwald Fellowship in 1948.

$\overline{22}$ http://schema-root.org/people/career/academics/economists/john_kenneth_galbraith/ 
Galbraith is considered as one of the greatest American economists of the twentieth Century and the architect of what we understand as liberal economics (Parker 2006). He published widely in the popular press with 46 books selling more than seven million copies (Parker 2006). His work in economics, politics, and literature have earned him the Medal of Freedom twice, the highest honor given to a civilian by the U.S. government (Holt 2013). Galbraith was an advisor to John F. Kennedy and other democratic office holders and used his influence to promote his graduate students. Myers asserts that Galbraith-along with John D. Black-opened the doors of the Bureau of Labor Statistics to him when he graduated in 1949.

After a brief stint at the Bureau of Labor Statistics, Myers was hired as a tenured Associate Professor at Morgan State College from 1950 to 1962. He served in the US State Department as the financial advisor to Latin America in the Agency for International Development from 1963 to 1967 . In 1967, he was appointed the president of Bowie State College, where he served until 1977. He was president of the President of National Association for Equal Opportunity in Higher Education from 1977 to 1998 and Chairman of Minority Access, Inc. from 1998 to the present.

\section{Samuel Za Zu Westerfield Jr.}

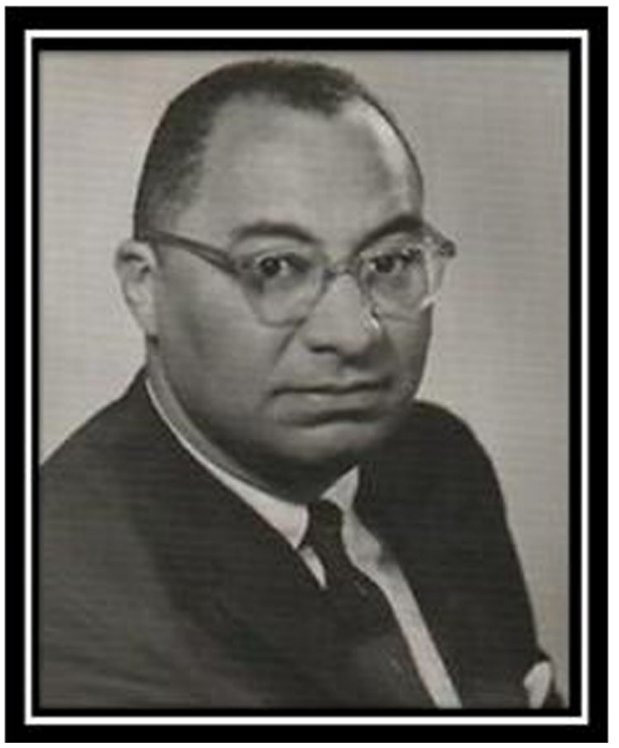

Washington Post. Samuel Z. Westerfield.jpg, 1972.

The sixth black to receive a Ph.D. in economics from Harvard University was Samuel Z. Westerfield, Jr. Westerfield was the son of the first black recipient of the Ph.D. in engineering from the University of Nebraska (Westerfield, Samuel Z. (1920-1972)). He grew up in an affluent part of segregated Washington, D.C., attended the prestigious Dunbar High School, and graduated Magna Cum Laude from Howard University in 1939. He was a 1941 recipient of a Rosenwald Fellowship to attend Harvard University, from which he received his M.A. in 1949 and his Ph.D. in 1951. His dissertation, "American Investment 
Companies and the Money Market, 1900-1950, a Study of their Origin, Development and Economic Significance" was an economic history of the evolution of investment trusts in Britain and the rise of investment companies in the United States. He traces the transformation of investment companies into the early twentieth Century and details the various forms and structures of these companies. The core part of the dissertation explores the diversification strategies of investment companies and the composition of their portfolios. He argues that these portfolios reflected shares in existing - mostly established - firms, and therefore, investment companies do not contribute much to capital markets for the funding of new enterprises. He details the management abuses and fraudulent activities of many of the British investment trusts, including those that were heavily involved in speculative investments in South Africa, Argentina and elsewhere. He points out that much of this abuse arose from managers who were promoting high risk - high return stocks in direct contradiction of the purported goals and objectives of their clients. Upon this backdrop of fraud and corruption in the investment trust industry, Westerfield sketches the rise of investment companies in the United States that were subjected to various forms of government regulations designed to limit the excesses of managers. He examines the rise of "expert managers" whose interests in minimizing risks in the portfolios resulted in the recycling of stocks rather than expansion of credit for new enterprises. He concludes that investment companies in the post 1920 s era in the USA could not be relied on as a source of macroeconomic expansion or policy implementation related to credit markets.

Westerfield's dissertation apparently was the inspiration for his early professional advancement. He served as the Dean of the Business School at Atlanta University; was a visiting professor at the Harvard Business School and then was appointed to several senior advisory and managerial positions at the Treasury Department during the Kennedy Administration, including Deputy Director of the Debt Analysis Staff and Deputy Director of the Office of International Affairs. Later, he became Deputy Assistant Secretary of State for African Affairs, 1967-1969; and then Ambassador Extraordinary and Plenipotentiary to Liberia, 1969-1972. He died in Liberia of a heart attack in 1972.

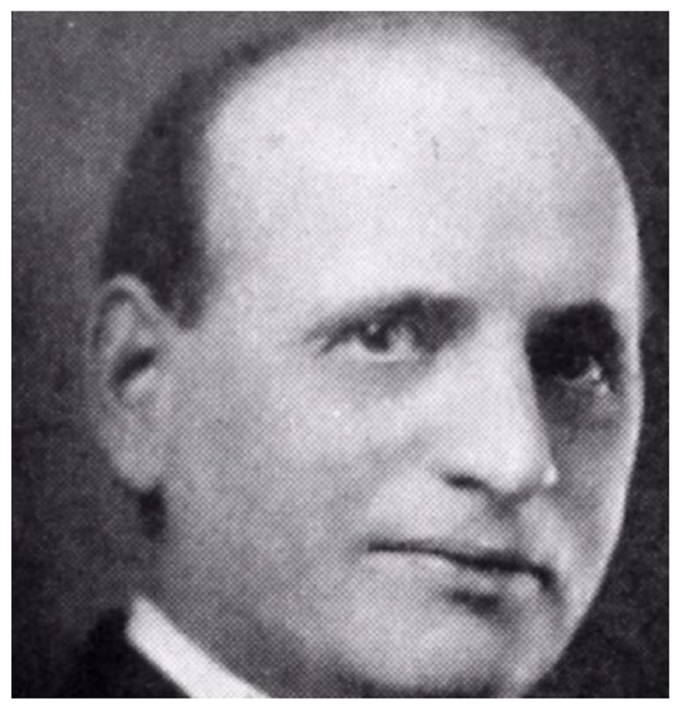

Harvard Economics. John Henry Williams.jpg. 
Westerfield's dissertation adviser was John Henry Williams (In Memoriam 1980). Williams was born in Wales, attended Brown University and received his Ph.D. in economics from Harvard University in 1919, winning the Wells Prize for his study of Argentine trade. His fields at Harvard were international economics and money and banking. He served as a Professor of Economics at Harvard University from 1921 to 1957. He also served as an assistant Federal Reserve agent, splitting his time between Harvard and the Federal Reserve Bank. Williams was the first Dean of the Harvard Graduate School of Public Administration (1937-1947) and served as the president of the American Economic Association in 1951.

Westerfield benefited not only from an extremely well-known and well connected dissertation advisor with close ties to policy makers in Washington, D.C.; he also benefited from having as his second reader, Alvin Hansen, the former University of Minnesota professor who was brought to Harvard as the Littaur Professor of Political Economy, where he joined former Minnesota colleague, John D. Black. Hansen, aside from being the co-creator of the IS-LM apparatus in Keynesian macroeconomics, was also involved in the original formation of the Council of Economic Advisors, one of the leading platforms for promotion of economic policies within the White House. In short, Westerfield was connected in multiple ways with the Harvard-Washington, D.C. network.

\section{A Model of the Production of Black Ph.D.'s in Economics at Harvard University}

There were 609 Ph.D.'s awarded by the Economics Department at Harvard University between 1905 and 1955. Six of these degrees were awarded to known blacks, five of whom were native-born African Americans. Three of them wrote "Theory" dissertations, rudimentarily measured by whether the word "theory" was included in the title. Only one received an undergraduate degree from Harvard University. All received their doctoral degrees following the presidential tenure of A(bbott) Lawrence Lowell (Term: 1909-1933), noted for his opposition to the admission of black and Jewish students. Class sizes before and during the war were relatively small. After the war, class sizes grew exponentially. And, five of the six blacks had some involvement with the Rosenwald Fellowship Program.

Julius Rosenwald, president of Sears and Roebuck, established the Rosenwald Fund. According to Jayne Beilke, Rosenwald was an admirer of Booker T. Washington and an advocate for "Washington's philosophy of racial uplift, which held that the disadvantages of race and class should be overcome through individual perseverance and self-reliance rather than by revolutionary methods." (Beilke 1997, p. 5) The early activities of the Rosenwald Fund focused on advocating for industrial arts and home economics, nursing, and elementary education in southern segregated schools. The fund, located in Chicago, shifted its focus after the hiring of Edwin Rogers Embree, the Yale-educated social scientist and grandson of the founder of Berea College. Embree had been a vice president of the Rockefeller Foundation and an admirer of W.E.B. DuBois and the concept of the talented tenth (Beilke 1997, p. 6).

Measuring the "Rosenwald Effect" in the model of the production of black Harvard Ph.D.'s in economics is relevant because the effect is not isolated to blacks, unlike such 
Table 1 Estimates of coefficients in logistic model of the probability of a black economics Ph.D. at Harvard, 1905-1955

\begin{tabular}{|c|c|c|c|c|c|c|}
\hline \multicolumn{7}{|l|}{ Logistic Regression } \\
\hline $\begin{array}{l}\text { Log pseudo likelihood }= \\
\quad-15.459095\end{array}$ & $\begin{array}{l}\text { Number of } \\
\text { obs }=609\end{array}$ & $\begin{array}{l}\text { Wald } \\
\qquad \operatorname{chi} 2(4)=43.13\end{array}$ & & $\begin{array}{l}\text { Psuedo } \mathrm{R} 2=0.5411 \\
\text { Prob }>\text { chi } 2=0.00000\end{array}$ & & \\
\hline Variable: & Coef. & Robust Std. Err & $\mathrm{z}$ & $\mathrm{P}>[\mathrm{z}]$ & [95\% Conf. & Interval] \\
\hline Theory & 2.415164 & 1.168123 & 2.07 & 0.039 & 0.1256851 & 4.704642 \\
\hline RosenwaldF & 7.369026 & 2.050893 & 3.59 & 0.000 & 3.34935 & 11.3887 \\
\hline Harvard & 1.757303 & 1.356362 & 1.3 & 0.195 & -0.9011173 & 4.415723 \\
\hline Relative Size & -19.5808 & 19.40743 & -1.01 & 0.313 & -57.61867 & 18.45706 \\
\hline Constant & -6.16125 & 1.084137 & -5.68 & 0.000 & -8.286115 & -4.03638 \\
\hline
\end{tabular}

tautological variables as "born in the south" or "received a degree after Lowell's presidency." Not all of the blacks received this fellowship and some whites also received the fellowship. Beilke reports, “....by the time the Fund officially ceased operations in 1948, it had dispensed a total of $\$ 1,832,830$ in fellowship awards to 1,537 individuals, including 999 Blacks and 538 Whites." (Beilke 1997, p. 13) Of the 609 recipients of the Ph.D. in economics at Harvard, three were white beneficiaries of the Rosenwald Fellowship. ${ }^{23}$ White Southerners, the fellowship committee believed, could contribute to improved race relations if they attended Northern graduate schools where they might interact with black intellectuals and develop an appreciation for the benefits of integration (Beilke 1997).

Our model of the production of black Ph.D.'s in economics at Harvard University incorporates the following determinants: the Rosenwald Effect; theory dissertation; the size of class; southern undergraduate institution; and whether the recipient held a Harvard undergraduate degree. The dependent variable in the model is the probability that a Harvard Ph.D. recipient is black. We obtained maximum likelihood estimates in a logistic model of the probability of a black recipient $b$, in time $t$, conditional on whether the recipient was awarded a Rosenwald Fellowship (R), and other variables, $x$.

$$
p\left(b_{t} \mid x_{t} ; R\right)=\frac{1}{1+e^{-\sum \beta_{i t} x_{i t}-\phi_{t} R_{t}}}
$$

The model is estimated using data on all doctorates awarded in economics, 19051955 ( $n=609$ ), with coding for whether the dissertation was a theory dissertation; the relative size of the class; Rosenwald Fellowship; and the Harvard undergraduate degree. Table 1 reports the results.

The pseudo R-squared is $.5411(p=.0000)$. The effects of theory dissertation and Rosenwald Fellowship are both positive and statistically significant at the $5 \%$ level.

\footnotetext{
${ }^{23}$ Jesse William Markham, Chief Economist, Federal Trade Commission and Professor at Harvard Business School; James Gray Maddox, US Department of Agriculture; Willis Duke Weatherford, Jr., President of Berea College, (1967-1984), Professor of Economics, Swarthmore (1948 until 1964), Dean, Carleton College (1965-1967).
} 
One can compute the exponential of the estimated coefficients to obtain the difference in odds ratios associated with the dichotomous variables. The odds of a black recipient of the Harvard Ph.D. in economics are 11 times higher when the thesis is a theory thesis; the odds of a black recipient of the Harvard Ph.D. in economics are a whopping 1586 times higher if there is an award of a Rosenwald Fellowship. The effects of a Harvard undergraduate degree and relative class size are statistically insignificant. The Rosenwald Effect is clearly a major contributor to the production of black Ph.D.'s at Harvard.

\section{Common Features}

The aforementioned brief summaries of the first six black Ph.D.'s in economics at Harvard and the simple econometric test do not do justice to the full range of connecting factors that contributed to their matriculation at, arguably, the premier economics department in the United States during the period of 1930's-1950's. Nevertheless, some common themes emerge when one looks more closely at the personal backgrounds and social moorings of the first six. Figure 3 captures the salient features of four central themes that link the first six black Ph.D.'s in economics at Harvard University: classical high school training; the influence of John D. Black; the role of black fraternal organizations; and the impact of the Rosenwald Fund. The solid lines denote a direct relationship between the common theme and the black Harvard $\mathrm{Ph} . \mathrm{D}$. in economics. The dotted lines reveal an indirect or suggestive relationship between the common theme and the black Harvard economics Ph.D. recipient.

Classical High School Training All six attended "classical" high schools with curricula that emphasized Latin, Greek, the history of philosophy, the physical sciences, and classical literature. Washington, D.C.'s Dunbar High School (the M Street School)

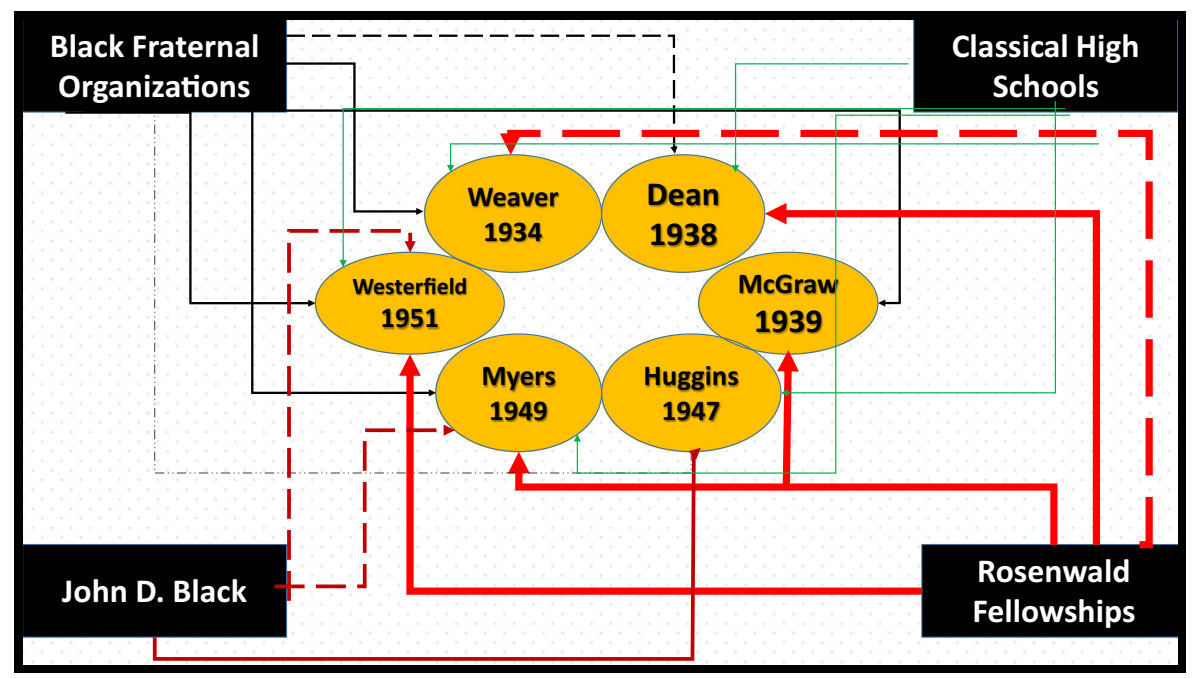

Fig. 3 Salient features of four central themes 
was once regarded as the preeminent black high school in America. A close second or comparable black high school was Frederick Douglass High School in Baltimore, Maryland. Weaver and Westerfield attended Dunbar High School, and Dean and Myers attended Douglass High School. McGraw attended a comparable high school associated with Atlanta University and Huggins attended a private British-run preparatory school. The classical training was quite unusual for black secondary education in the first half of the twentieth Century. Most black high schools in the South mirrored the emphasis of Booker T. Washington on industrial arts and home economics. Elite high school training was neither necessary nor expected for entrants to the vast majority of Historically Black Colleges and Universities. Nonetheless, these classical high schools provided comparable training to Boston Latin, Philadelphia Central and Baltimore City College, the three oldest public high schools in the United States and historic public school pipelines to the Ivy League. That all of these black economists had classical high school training arguably helps to explain how they were able to compete in the graduate program with white graduates at Harvard College, MIT, Stanford, Brown and other undergraduate institutions that sent scores of their graduates to Harvard's economics department.

The importance of the classical high school training cannot be understated. For example, Frederick Douglass High School produced not just Harvard economists Dean and Myers. It also produced the first black female Ph.D. in economics from Yale University, Phyllis Wallace. In his dissertation detailing the curriculum at Douglass High School, its principal, Mason Hawkins, reveals his preference for hiring graduates of Amherst, Williams, Bowdoin, and other prominent liberal arts colleges. Not only did Dean and Myers aspire for training in economics at Harvard, but they were also taught by and mentored by faculty from institutions that serve as pipelines to Harvard for whites.

Perhaps the box labeled "Classical High Schools" could be re-labeled "Classical Training" since the graduates of Morgan and Howard also shared a similar characteristic: faculty members with ties to Harvard. To illustrate this point, consider the case of Douglass graduate Samuel Myers. Myers' two main influencers at Morgan College were Clinton Everett Knox (European History) and Leon Wright (Philosophy and Religion). Knox received his undergraduate education at Williams College (1930) and graduate degrees from Brown (1931) and Harvard (1940). Wright received his degree from Harvard Divinity School. Thus, the seeds of aspiration to attend Harvard planted by Mason Hawkins at Frederick Douglass High School, were fertilized and watered in the years at Morgan.

The Influence of John D. Black Black was the Huggins' thesis advisor. He was Myers' mentor, even though Black's protégé, John Kenneth Galbraith was Myers' formal thesis advisor. Westerfield's second committee member was Alvin Hanson, who had been Black's close colleague at the University of Minnesota. Black had come to Harvard years before Hanson was hired. Beyond Black's formal role in advising the two of the six African American graduates was his apparent friendship with and support for Westerfield and McGraw, whose fields, however, were distant from Black's core areas of specialty. Oral histories and anecdotes from Samuel Myers confirm that Black was accessible and genuinely helpful to African American students. This mentorship role may be difficult to 
measure or operationalize, but it undoubtedly was a key factor in assuring that blacks admitted ultimately graduated. ${ }^{24}$

Black Fraternal Organizations Robert Weaver was a member of Omega Psi Phi Fraternity, the second oldest black college fraternity formed at Howard University on November 17, 1911, by Edgar Amos Love, Oscar James Cooper, Frank Coleman, and the celebrated MIT-affiliated zoologist, Ernest Everett Just. Westerfield, McGraw and Myers were all members of Alpha Phi Alpha Fraternity, the oldest black college fraternity. Alpha Phi Alpha boasts among its members Thurgood Marshall, Martin Luther King, Ernest Morial, Andrew Young, W.E.B. Dubois, Paul Robeson, David Blackwell, and Jesse Owens. Huggins' connection to Alpha owes to his attending Cornell University, where Alpha Phi Alpha fraternity was founded in 1906. Dean's connection to Alpha owes to his marriage to the daughter of the president of the Harlem Alphas and his receipt of a scholarship from the Baltimore graduate chapter of Alpha Phi Alpha (Delta Lambda Chapter) to attend Bowdoin. Dean's father-in-law was also a member of Sigma Pi Phi Fraternity, the first professional black fraternity founded in 1904. Weaver, Westerfield, and Myers were known members of Sigma Pi Phi. All but two were Rosenwald Fellows.

Rosenwald Fellowships Four of the six black Harvard Ph.D.'s received one or more Rosenwald Fellowships: Dean, McGraw, Myers and Westerfield. Robert Weaver served on the Rosenwald selection committee in the 1940's. Huggins may not have been eligible for the Rosenwald fellowship that was intended for US blacks. The importance of the Rosenwald Fellowships is not limited to the influence on the production of black Ph.D.'s in economics at Harvard University. Virtually all of the black economists produced in the first half of the twentieth Century were Rosenwald Fellows. From Stephanie Deutsch's original reviews of the Rosenwald Fund Archives, Table 2 reports the full list of Rosenwald Fellows studying economics. Prominent among the recipients were University of Chicago Professor Abram Harris (Columbia University graduate); Phyllis Wallace (Yale graduate), who served as a Professor at the Sloan School of Management, MIT; and Mabel Murphy Smythe, (Mount Holyoke graduate, University of Wisconsin Ph.D. in labor Economics). Dr. Smythe was U.S. Ambassador to Cameroon and to the Republic of Equatorial Guinea, served as Deputy Assistant Secretary of State for African Affairs and held an endowed professorship at Northwestern University as the director of its African Studies Program.

\section{Outcomes}

To the four main themes that help explain how the six black Ph.D.'s in economics emerged from Harvard, one must add the central outcome associated with their professional lives. All six gravitated towards careers where they contributed to black

\footnotetext{
${ }^{24}$ I do not have data on persons enrolled in the Ph.D. who did not graduate. However, Myers' contention is that about a third of his class never obtained the Ph.D. but he knows of no other African Americans who matriculated while he was there who did not complete their degrees.
} 


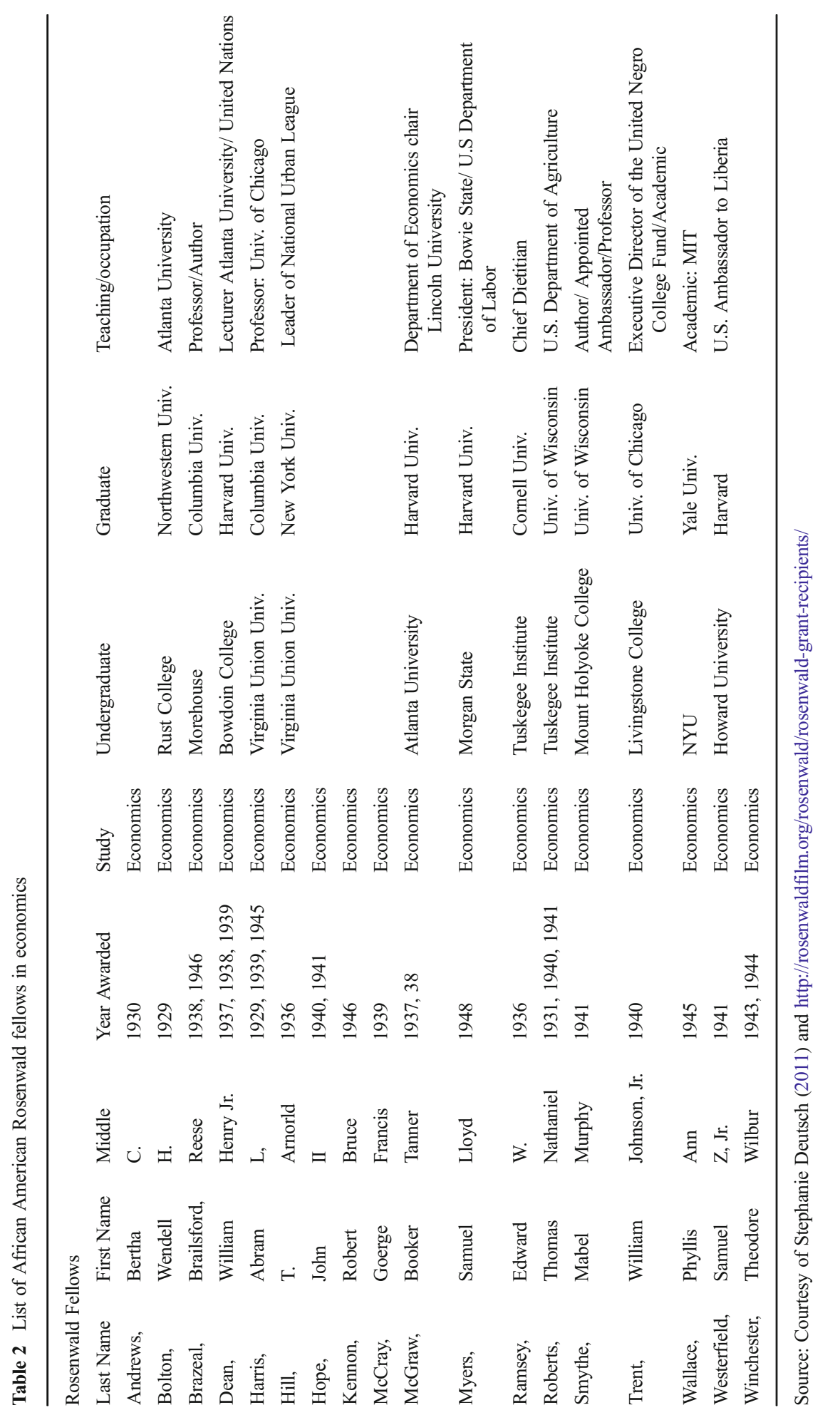


empowerment. All were involved in black higher education and/or black empowerment in one way or another.

While one might argue that Dean's relegation to Atlanta University when major research universities refused to hire him was a setback, others like Westerfield and Myers relished their roles as mentors and administrators at Historically Black Colleges and Universities (HBCUs). Huggins was distressed by the student revolts that led to his departure from the University of West Indies, but all indications reveal that his deepest passion and commitment was the empowerment of his students and black economic development policies in the former British colonies. McGraw, after a successful academic career at several HBCUs, settled into the behind-the-scenes role of Washington, D.C. policy advocate, where he focused on promoting housing policies that improved the well-being of blacks.

Dean's work at the United Nations, while a distinct shift from his theoretical studies of location and economic development, showed his ability to apply economic theory to pressing problems confronting blacks in Africa and the Caribbean. Westerfield is still remembered for his enhancement of the school of business at Atlanta University. Weaver's tenure as the Secretary of the U.S. Department of Housing and Urban Development provided him a highly visible platform for confronting the housing crisis that faced black Americans in the post-World War II era. In short, all six pursued careers that gravitated towards using their training at Harvard as springboards to improving the lives of blacks elsewhere.

\section{Implications for Twenty-First Century}

Harvard University still struggles to attract highly qualified black graduate students into its economics program. Surprisingly, many at Harvard are unaware of the successful production of black Ph.D.'s in economics during the era of state-enforced segregation from the 1930's to the 1950's. Not knowing that there have been success stories from the past can be an unnecessary burden on those committed to advancing the prospects of minorities in the profession in the future. Worse, not knowing about the past successes can fuel the perception that current limitations on producing black doctorates in economics are related to the poor preparation and lower abilities of blacks, as opposed to other structural explanations, including outright bias and discrimination among sentinels at the gateways to the profession.

The most important take-away when looking at the empirical evidence of the production of black Ph.D.'s during an era when blacks were not expected to excel, let alone attend Harvard, is that financial aid and prestigious scholarships can spell the difference between one or two Ph.D.'s produced and a half-dozen successful doctorates. The Rosenwald Fund contributed to the production of black Ph.D.'s at other top research universities. The selection process was rigorous; the applicants were expected to contribute to the improvement in race relations and to finding solutions to problems facing African Americans; and the funding was sufficient to assure that recipients could devote their time to completing their degrees. Because of the retrenchment of raceconscious programs in the 1990 's, there is no large funding source analogous to the Rosenwald Fellowship. It is notable, moreover, that the Rosenwald Fellows included whites as well. For example, classmate of Myers and Westerfield, Willis Duke 
Weatherford, Jr., went on to become the president of Berea College, transforming its admissions policies so that it became a leader in attracting highly motivated African Americans, along with low-income whites. As such, the Rosenwald Fellowship would have survived current challenges to minority scholarship programs and still achieved its goals of promoting racial equality.

Another take-away is that strong academic backgrounds appropriate for preparing people for careers in economics require starting as early as high school. The classical high school training that all of the six black Harvard Ph.D. recipients encountered mirrored the type of training that white students at elite colleges received in the early twentieth Century. These six were equipped with the language and the cultural moorings typical of their classmates at Harvard. This early indoctrination into the culture of higher education prepared them for success at Harvard. Ignoring the importance of early preparation can doom to failure otherwise well-intentioned programs.

Much has changed about the economics profession since the days when my father studied. The economics I encountered at MIT was much unlike the economics my father encountered at Harvard. The episodic changes in the core approaches and methodologies of the profession mean that each generation will need to adopt new and innovative strategies for preparing underrepresented groups for the economics profession. Nonetheless, there remain some common underpinnings for entry into the profession that we can learn from observing the lives of the first six at Harvard.

One common underpinning is the value of a timely introduction to the study of the field. Strong high school preparation for eventual careers in economics requires an early introduction to economics as a field and the questions that economics addresses. Instead of making the study removed from everyday life and emphasizing the remote and abstract parts of the core tools of the profession, advocates for increasing access to the profession among racial and ethnic minority groups need to embrace simplicity and focus on questions that young people care about. Far more people watched the Super Bowl and the Grammy Awards than those who watch Bloomberg News. So, what is it about economics that can answer questions about sports stadiums or about the marketing of hip-hop? Surprisingly, few economists venture into these areas of inquiry that ordinarily would attract high school students.

But, to attract future black intellectuals to the profession, one must also offer a candid history of the profession, including the contributions of black economists to the history of the economic ideas. Unfortunately, the history of economic thought rarely discusses the economic thoughts of African Americans and, worse, courses on the history of economic thought are rarely required in graduate or undergraduate training in economics - with or without reference to the contributions of African Americans. If one wants a clear-cut prescription for turning economics off to future black students, simply ignore any and all of the contributions that blacks themselves have made to the profession.

A final take-away from reviewing the lives of the first six blacks to receive Ph.D.'s in economics at Harvard is the role of the community of minority scholars. My 95 year old father got it right: he was indeed the fifth black Ph.D. in economics at Harvard. He knew these men, or he knew of these men. He can be forgiven if, in his 90's, he had forgotten many of the dates and names. But, he embraced the qualities that proved common among his black Harvard classmates and contemporaries: a commitment to buiding a community of scholars. He was a close friend of Samuel Westerfield; he 
interacted regularly with Robert Weaver and Andrew Brimmer, whose Harvard degree was awarded in 1957; he remained in contact with Phyllis Wallace, Marcus Alexis, and Clifton Wharton, and by extension with a large network of other prominent black economists like Margaret Simms, a former Vice-President of the Joint Center for Political and Economic Studies and Bernard Anderson, the first tenured black professor at the Wharton School and former Asisstant Secretary of the U.S. Department of Labor.

These lifetime linkages since have become formalized first in the creation of the Caucus of Black Economists and later, in the establishment of the National Economic Association. These strong networks overlap with other professional and fraternal organizations. Clifton Wharton, Bernard Anderson, Marcus Alexis, Samuel Z. Westerfield, and Booker T. McGraw all shared, not just the common bond of being black economists, but also numerous fraternal bonds as well. ${ }^{25}$ The resulting social networks assured that they could call on one another for support of their professional ambitions related to building and enhancing opportunities for African Americans. Recognition of those fraternal bonds is not a call for a renewal of what might be called "the old black male network." For surely, the doors opened by these pioneers were intended to advance opportunities for all oppressed minorities, as well as for women within the profession. However, the lessons learned about how these leaders were able to forge professional ties through their social and fraternal networks should challenge the view that black intellectuals should divorce themselves from their own organizations in order to achieve legitimacy within the white world.

Acknowledgements Lawrence Karongo, Department of Applied Economics and the Humphrey School of Public Affairs, provided valuable research assistance. I am grateful to William A. Darity, Jr. for our extended conversations; to Robert Solow, for observations and recollections about training of Harvard Ph.D.'s during the 1940s; to Samuel L. Myers, Sr., for detailed accounts of his experiences at Harvard's economics department in 1942 and from 1945 to 1949. I have relied on Gregory Price's original database of black economists. I am indebted to Stephanie Deutsch for access to Rosenwald Fellowship files; to Margaret Simms for her incredible memory and sharing of her family history connecting the dots among black economists teaching in Atlanta, Michigan and Missouri before the Second World War; to Bernard Anderson for insights about Sigma Pi Phi and Alpha Phi Alpha connections to black economists; to Cheniqua Johnson for her discovery of many lost Harvard dissertations; to Lawrence Karongo for his long hours collecting Harvard dissertations and painstakingly entering data; to William Darity for his encouragement and constant feedback. Participants in the summer workshop of the National Economic Association and the Association of Hispanic Economists at Bucknell University provided comments and feedback on this paper. Professor Nina Banks provided a congenial and productive environment for the discussion of the paper and offered many useful suggestions. I am grateful to the many donors to the Wilkins Center, whose generosity made possible the research for this paper: The Humphrey School of Public Affairs; The Minnesota Population Center; Educational Testing Service; Minority Access, Inc.; Thomson Reuters; University of Maryland Foundation; Benedict College; Committee on the Status of Minority Groups in the Economics Profession; Optimal Solutions; Langston University; Morehouse College; Spelman College; Howard University Economics Department; Alumni Association, Morgan State University Foundation; Thomas D. Boston; Office for Diversity in Graduate Education at the University of Minnesota; TRIO McNair Scholars Program at the University of Minnesota; Institute of Ethnology and Anthropology, Chinese Academy of Social Sciences; Baltimore City College; Applied Economics Ph.D. Program, University of Minnesota; National Law School of India University, Bangalore; Professor Sukhadeo Thorat, Jawaharlal Nehru University, Chairman, Indian Council

\footnotetext{
${ }^{25}$ Marcus Alexis was a member of Mu Chapter of Alpha Phi Alpha at the University of Minnesota. Bernard Anderson, also a member of Alpha Phi Alpha, was the chair of the social policy committee of Sigma Pi Phi Fraternity for many years. He was a member of the Alpha Boulé in Philadelphia and active in Epsilon Boulé in Washington D.C .He served as Deputy Secretary of the U.S. Department of Labor. Andrew Brimmer was also member of Epsilon Boulé of Sigma Pi Phi. Myers is a member of Gamma Boulé of Sigma Pi Phi, whose charter includes Mason Hawkins as one of its founders.
} 
of Social Science Research New Delhi, India; Robert L. Ryan; Sigma Pi Phi, Omicron Boulé; Sheila Diann Ards and Angela Myers; Caroline Hoxby; Ejim, Andrea, and Alexander Achi; Cornelius May and Patricia Whyte. Judy Leahy-Grimes, Wilkins Center Executive Assistant (1992-2004), Lawrencina Oramalu (Associate Director, 1999-2006), Blanca Monter (Associate Program Director, 2007-2016) and Akua Asare (Coordinator, 2014-2015) all provided unparalleled administrative assistance to this project.

\section{References}

About Department of Economics. Harvard University Retrieved from http://economics.harvard. edu/pages/about. Accessed 15 Mar 2016.

Abram Harris Born African American Registry: a non-profit education organization. Retrived from http://www.aaregistry.org/historic_events/view/abram-harris-born. Accessed 15 Mar 2016.

Appiah A, Gates LH, editors. Africana: the encyclopedia of the African and African American experience. New York: Oxford University Press; 2005.

Armstrong R, Pendergast S. 2005. Weaver, Robert C 1907-1997. In Encyclopedia.com. Retrieved from http://www.encyclopedia.com/topic/Robert_Clifton_Weaver.aspx. Accessed 16 Mar 2016.

Backhouse RE. Paul A. Samuelson's departure from Harvard to MIT. University of Birmingham; 2013. Working paper. Retrieved from http://citeseerx.ist.psu.edu/viewdoc/download?doi=10.1.1.303.1364 \&rep=rep1\&type=pdf.

Barron J. Robert C. Weaver, 89, first black cabinet member, dies. The New York Times; 1997, July 19. Retrieved from http://www.nytimes.com/1997/07/19/nyregion/robert-c-weaver-89-first-black-cabinetmember-dies.html. Accessed 15 Mar 2016.

Beilke JR. The changing emphasis of the Rosenwald fellowship program, 1928-1948. J Negro Educ. Winter 1997;66(1):3-15.

Black E. Hitler's debt to America. The Guardian; 2004, February 5. Retrieved from http://www.theguardian. com/uk/2004/feb/06/race.usa. Accessed 15 Mar 2016.

Bombardieri M. The 'Harvard experience' redefined. The Boston Globe; 2004, April 27. Retrieved from https://archive.boston.com//news/education/higher/articles/2004/04/27/the_harvard_experience_ redefined/. Accessed 28 Mar 2016.

Brewer WM. William Henry Dean. The Journal of Negro History. 1953;38(1):134-6. Retrieved from http://www.jstor.org/stable/2715826

Capello R, Nijkamp P. Urban dynamics and growth: advances in urban economics. Amsterdam: Elsevier; 2004.

Cochrane WW. Remembering John D. Black. Choices. 1989; First Quarter: 30-32. Retrieved from http://ageconsearch.umn.edu/bitstream/130512/2/WillardCochrane.pdf. Accessed 15 Mar 2016.

Dean, William H. (1910-1952) - Economist, educator, chronology, becomes United Nations Africa Unit Chief, Directs Italian Somaliland mission. Economics. In Online Encyclopedia 1910-1952. Retrieved from http://encyclopedia.jrank.org/articles/pages/4202/Dean-William-H-1910-1952.html. Accessed 16 Mar 2016.

DeMarco JP. The rationale and foundation of DuBois's theory of economic cooperation. Phylon. 1974;35(1): 5-15. Retrieved from http://users.clas.ufl.edu/marilynm/Theorizing_Black_America_Syllabus_ files/DuBois_\%20Theory_of_Economic_Cooperation.pdf.

Deutsch S. You need a schoolhouse: Booker T. Washington, Julius Rosenwald, and the building of schools for the segregated south. Evanston: Northwestern University Press; 2011.

Dr. Wm. Dean, Former A. U. Professor Found Dead in N.Y. 1952, January 10. Atlanta daily world. Retrieved from http://search.proquest.com.ezp1.lib.umn.edu/docview/490964616?accountid=14586. Accessed 17 Mar 2016.

Dudley Huggins papers SC9 Retrieved from http:/uwispace.sta.uwi.edu/dspace/bitstream/handle/2139/10169 /dudleyhuggins.html?sequence=1\#toc. Accessed 15 Mar 2016.

Ellison J. Celestial mechanics and the location theory of William H. Dean, Jr., 1930-52. Am Econ Rev. 1991;81(2):315-7.

Feathers T. Robert Bishop; professor led economics department of MIT. The Boston Globe; 2013, March 30. Retrieved from https:/www.bostonglobe.com/metro/2013/03/29/robert-bishop-economist-was-professordean-mit/9EogTxhKTjCG83UUM6ExNN/story.html. Accessed 15 Mar 2016.

Grant M. The passing of the great race. Geogr Rev. 1916;2(5):354-60. 
Greene D. The Jewish origins of cultural pluralism: the menorah association and American diversity. Bloomington: Indiana University Press; 2011.

Greene WW. Some comments on economic theory: Presidential address by Winfield W. Greene. Casualty Actuarial Society 1936;XXII,Part II(46). Retrieved from https://www.casact. org/pubs/proceed/proceed35/35213.pdf. Accessed 29 Mar 2016.

Harris, Seymour Edwin, 1897-1974. National Archives Catalog Retrieved from https://catalog. archives.gov/id/10677980. Accessed 29 Mar 2016.

Harvard/Radcliffe on-line historical reference shelf: Annual reports. Retrieved from http://hul. harvard.edu/lib/archives/refshelf/AnnualReportsSearch.htm. Accessed 20 Mar 2016.

Harvard University. Quinquennial catalogue of the officers and graduates of Harvard University, 1636-1930. Cambridge: The University; 1930.

History of the Boulé. Sigma Pi Phi Fraternity Retrieved from https:/www.sigmapiphi.org/home/history-ofthe-boule.php?page=2. Accessed 15 Mar 2016.

History of the SAT: A Timeline. PBS. n.d. Retrieved from http://www.pbs. org/wgbh/pages/frontline/shows/sats/where/timeline.html. Accessed 15 Mar 2016.

Holt RPF. John Kenneth Galbraith. East Econ J. 2013;40(1):138-41.

Huggins HD. The economics research programme of British Guiana, 1933-1945. (Doctoral Dissertation). 1947.

Improving diversity in education, employment and research. Minority Access, Incorporated Retrieved from http://www.minorityaccess.org/us.html. Accessed 15 Mar 2016.

In Memoriam. John Henry Williams 1887-1980. FRBNY Quarterly Review. 1980-81;5(4):1-2. Retrieved from https://www.newyorkfed.org/medialibrary/media/research/quarterly_review/1980v5/v5n4article1. pdf

Isard W. A general location principle of an optimum space-economy. Econometrica. 1952;20(3):406-30. Retrieved from http://www.jstor.org/stable/1907412 doi:10.2307/1907412.

John D. Black Retrieved from https://www.aaea.org/trust/appreciation-clubs/john-d-black. Accessed 15 Mar 2016.

Leaver AH. Chapter 4 and 5. In Dudley Huggins: memoir of a west Indian's journey. Bloomington: AuthorHouse; 2010. Retrieved from https://dudleyhuggins.wordpress.com/2011/09/23/chapter4/. https://dudleyhuggins.wordpress.com/2011/09/23/chapter-5/. Accessed 17 Mar 2016.

Mason Albert Hawkins, Ph.D., Professor of Education at Morgan State College, Baltimore. Retrieved from http://collections.digitalmaryland.org/cdm/ref/collection/mdaa/id/145. Accessed 17 Mar 2016.

Mason ES, Lamont TS. The Harvard Department of Economics from the beginning to world war II. Q J Econ. 1982;97(3):383-433. Retrieved from http://www.jstor.org/stable/1885870

McHugh W. 1968. Booker T. McGraw Oral History-JFK \#1, 9/11/1968. John F. Kennedy Oral History Collection. Retrieved from https://www.jfklibrary.org/Asset-Viewer/Archives/JFKOH-BTM-01.aspx.

Molella AP. The longue duree of Abbott Payson Usher. Technol Cult. 2005;46(4):779-96.

Mulhere, K. 2 new challenges to affirmative action: lawsuits seek to end considerations of race in admissions at Harvard and U. of North Carolina at Chapel Hill. 2014, November 18. https://www.insidehighered. com/news/2014/11/18/lawsuits-allege-affirmative-action-violations.

Myers SL. 1942. Consumers' cooperation: a plan for the Negro (master of arts thesis) Retrieved from https://open.bu.edu/handle/2144/7251.

Myers SL. Product testing and labeling with special reference to textiles (doctoral dissertation). Cambridge: Harvard University; 1949.

NAACP History: W.E.B. Dubois. Retrieved from https://donate.naacp.org/pages/naacp-history-w.e.b.-dubois. Accessed 15 Mar 2016.

North DC. Location theory and regional economic growth. J Polit Econ. 1955;63(3):243-58.

Otani A. 2015. Ten elite schools where middle-class kids don’t pay tuition. Bloomberg Business. Retrieved from http://www.bloomberg.com/news/articles/2015-04-01/ten-elite-schools-where-middle-class-kidsdon-t-pay-tuition. Accessed 28 Mar 2016.

Parker R. J K Galbraith. RES Newsletter. 2006;132(July). Retrieved from http://www.res.org. uk/SpringboardWebApp/userfiles/res/file/obituaries/galbraith.pdf.

Powers E. The Harvard effect, Inside Higher Ed's News; 2006, Retrieved September 13, 2006. https:/www. insidehighered.com/news/2006/09/13/harvard.

Pritchett WE. Robert Clifton Weaver and the American city: the life and times of an urban reformer. Chicago: IL: University of Chicago Press; 2010.

Professor Ripley of Harvard Dies. New York Times; 1941.

Ripley WZ. The races of Europe; a sociological study (Lowell Institute lectures). New York: D. Appleton and Co.; 1899. 
Ripley WZ. Main street and wall street. New York: Arno Press; 1929. 1973. ISBN 0405051093

Ripley WZ. Railway problems. (2 vols). Beard Books. 2000. ISBN 1587980754.

Roberts S. Walter J. Leonard, pioneer of affirmative action in Harvard admissions, dies at 86. The New York Times; 2015, December 16. Retrieved from https://www.nytimes.com/2015/12/17 /education/walter-j-leonard-pioneer-of-affirmative-action-in-harvard-admissions-dies-at-86.html? $\mathrm{r}=0$. Accessed 08 Apr 2016.

Samuel Myers. 2003. In The History Makers. Retrieved from http://www.thehistorymakers. com/biography/samuel-myers-39.

Seymour Edwin Harris 1897-1975. History of Economic Thought Website Retrieved from http://www. hetwebsite.net/het/profiles/seharris.htm. Accessed 29 Mar 2016.

The Abbott Payson Usher Prize. Retrieved from http:/www.historyoftechnology.org/awards/usher.html. Accessed 17 Mar 2016.

The Black Cabinet Migration Resources Retrieved from http://www.inmotionaame.org/gallery/detail. cfm?id=487435\&type=image. Accessed 16 Mar 2016.

The Sphinx. (1955) Vol. 41(2) p. 2 Retrieved from https://issuu.com/apa1906network/docs/195504102.

The University. Summaries of theses accepted in partial fulfillment of the requirements for the degree of doctor of philosophy. Cambridge: The University; 1939.

Trescott PB. Jingji xue: the history of the introduction of western economic ideas into China, 1850-1950. Hong Kong: Chinese University Press; 2007.

Usher, AP. A history of mechanical inventions: revised edition. Mineola: Dover Publications; 2011.

Usher, Abbott P. International encyclopedia of the social sciences. Retrieved from Encyclopedia.com. http:/www.encyclopedia.com/social-sciences/applied-and-social-sciences-magazines/usher-abbott-p. Accessed 26 Mar 2016.

Weaver RC. The high wage theory of prosperity. In Chandler, William S. (ed.); Munson, Thornton S. (ed.); Weaver, Robert C.; McMahon, Winifred T. Franklin lectures, vol I, no. 1. Sunapee: Franklin Lectures, Inc; 1935.

Weaver RC. The high wage theory of prosperity. In Wilson, Francille Rusan, The segregated scholars: Black social scientists and the creation of Black labor studies, 1890-1950. Charlottesville, VA: University of Virginia Press; 2006.

Weaver RC. The urban complex: human values in urban life. Anchor Books: Doubleday; 1964.

Weaver RC. Dilemmas of urban America. Cambridge, MA: Harvard University Press; 1965.

Westerfield, Samuel Z. (1920-1972). In BlackPast.org: Remembered \& Reclaimed: An Online Reference Guide to African American History. Retrieved from www.blackpast.org/aah/westerfield-samuel-z-19201972.

William Z. Ripley. In New World Encyclopedia. Retrieved from http://www.newworldencyclopedia. org/entry/William_Z._Ripley. Accessed 15 Mar 2016.

Williamson ST. (1929, December 29). William Z Ripley-And Some Others New York Times p XX2.

Wilson FR. The segregated scholars: black social scientists and the creation of black labor studies, 1890-1950. Charlottesville and London: University of Virginia Press; 2006. 